\title{
THREE MODELS OF EQUALITY AND EUROPEAN ANTI-DISCRIMINATION LAW
}

\author{
Olivier De Schutter, Professor of Law, University of Louvain, \\ Belgium, and Global Law Professor at New York University; Co- \\ ordinator of the EU Network of Independent Experts on \\ Fundamental Rights
}

\section{Three Models of Equality}

Since the European Court of Justice first declared, in the 1976 Defrenne ('No. 2') case, ${ }^{1}$ that the principle of equal pay between men and women for the same work stated in Article 119 of the EEC Treaty should be recognized a direct effect in the relationships between private parties, at a time when the European legislator had just started to implement that provision of the Treaty of Rome, ${ }^{2}$ European law has made considerable progress in outlawing different forms of discrimination. In order to evaluate both what has been achieved thirty years later and which questions still remain, this article seeks to map the territory of European anti-discrimination law by locating its acquis within a broader theoretical framework. There are of course a number of ways to classify competing understandings of the requirement of equality, in order to identify the different "models" into which the principle of equal treatment may translate at the level of concrete legal rules. In this article, I seek to distinguish three such models, which I believe may serve to highlight the most important dilemmas facing European Law in its treatment of that principle.

The three models are defined on the basis of two questions which, I would submit, remain to a large extent open at the current stage of development of European anti-discrimination law. A first question concerns the aim of this body of law. In the implementation of the principle of equal treatment, do we seek to protect all individuals from being discriminated against, or do we seek to ensure an equal representation of the diverse social groups composing society in its different sectors, and to ensure a roughly equal distribution of all social goods among those groups? This alternative is sometimes presented as an alternative between formal (or de jure) equality and substantive (or de facto) equality, to which, indeed, it may intuitively correspond: it is not enough, we tend to say, to protect individuals from discrete acts of discrimination (whether they originate in the legal rules or whether they have their source in the behaviour of public officials or of other private persons); it is also necessary that all the groups of society have generally equal access to the scarce social goods, and that no fraction of the population is more or less permanently excluded from such goods.

1 Case 43/75, Defrenne v Sabena (No. 2) [1976] ECR 455 (judgment of 8 April 1976).

2 Directive 75/117/EEC on the approximation of the laws of the Member States relating to the application of the principle of equal pay for men and women, OJ L 45, 1975, p.19. 
However, this latter distinction is not particularly helpful, especially because it is strongly biased in favour of the second branch - who, after all, would not want equality to be "substantive", rather than merely "formal"? A much more enlightening approach is the one proposed by Amartya Sen in his Inequality Reexamined, where he insists that the central question is not whether or not we want equality, formal or substantive, ${ }^{3}$ but with respect to what the requirement of equality is imposed. The ineliminable (and indeed desirable) differences between individuals mean that, if equality is imposed with respect to one good, that requirement will necessarily result in inequalities with respect to the distribution of other goods. For instance, if we insist on all individuals being treated equally (i.e., without discrimination) in the recruitment process in the context of employment, we necessarily must accept that this may result in certain groups (generally white, neither too young nor too old, mostly male at least in certain professions, and belonging to the upper or middle social class) will be overrepresented in certain sectors or at certain levels of the professional ladder. This imbalance is perfectly compatible with a strict enforcement of the prohibition to commit any discrimination in the selection of job applicants: it is simply the mechanical result of the fact that the qualities which may legitimately be rewarded in the examination of job candidacies (in particular, certain levels of educational achievement or the mastery of cultural codes) are unequally distributed among different groups of the population. So we must choose between insisting on equal treatment in the recruitment process (so that the chances of all are equal) and insisting on equal treatment in the allocation of jobs (so that all groups are roughly represented in each sector and, within each sector, at each level of the hierarchy, in proportion to their representation within the population).

A second question on the basis of which we may seek to identify models of equality relates to the visibility - versus the invisibility - of the "suspect" characteristics attached to individuals, and which may give rise to discriminatory attitudes or treatment. Here again, we may have to choose between two routes. Either we consider that shielding such characteristics from the view of others, through a strict understanding of the requirements of personal data protection rules, will protect individuals presenting those traits from the risk of discrimination - if she ignores the religion of one person, for instance, the employer will not be able to commit a discrimination against that person: even if she intended to do so, her discriminatory impulse would have nothing to hold upon. Or we consider, instead, that "suspect" characteristics should be considered explicitly if equality is to be effective. The choice in favour of taking characteristics such as, for instance, race or ethnic origin, or age, into account - whether in the decisions to be taken by the rule-maker or in the formulation of public policies, or in the decisions of the private employer or of the educational institution - may be motivated, first, by the recognition that there is no other way to proceed. Age, for instance, or even to a large extent race or ethnic origin, just like gender, simply cannot be hidden. They are made visible in the course of everyday

3 Indeed, as Sen notes, "every normative theory of social arrangement that has at all stood the test of time seems to demand equality of something - something that is regarded as particularly important in that theory" (Sen, Inequality Reexamined (1992), p.12). 
social interactions as well as in procedures such as job interviews. Better, then, to recognize that these characteristics may play a role in decisionmaking and that, therefore, the impact of decisions which may have been influenced by those factors should be carefully monitored in order to guard against discrimination, than to ignore the influence they may be exercising. Second however, and more importantly, the choice to take these traits into account may be justified by the desire to move from a negative approach to equality to a positive approach: while the negative approach may be understood as a prohibition to commit acts of discrimination, the positive approach should be seen as imposing an obligation to affirmatively promote equality, through tools such as affirmative action policies, action plans in favour of diversity, or other positive action measures. ${ }^{4}$

By combining these two alternatives, we arrive at a very simple matrix of "models of equality". These models refer both to different understandings of the requirements of the principle of equal treatment and to precise legal regimes which implement these different understandings:

\begin{tabular}{|c|c|c|c|}
\hline & \multicolumn{3}{|c|}{$\begin{array}{l}\text { The aim of imposing a requirement of equal } \\
\text { treatment }\end{array}$} \\
\hline \multirow{3}{*}{$\begin{array}{l}\text { Combination of } \\
\text { the principle of } \\
\text { equal treatment } \\
\text { with the } \\
\text { requirements of } \\
\text { privacy }\end{array}$} & & Non-discrimination & $\begin{array}{l}\text { Proportionate } \\
\text { representation }\end{array}$ \\
\hline & $\begin{array}{l}\text { Invisibility of } \\
\text { suspect } \\
\text { characteristics }\end{array}$ & $\begin{array}{l}\text { Prohibition of } \\
\text { discrimination }\end{array}$ & \\
\hline & $\begin{array}{l}\text { Visibility of } \\
\text { suspect } \\
\text { characteristics }\end{array}$ & $\begin{array}{l}\text { Prohibition of } \\
\text { discrimination, } \\
\text { including disparate } \\
\text { impact } \\
\text { discrimination }\end{array}$ & $\begin{array}{l}\text { Affirmative } \\
\text { equality }\end{array}$ \\
\hline
\end{tabular}

In this matrix, one of the cells is empty. This simply expresses the fact that an understanding of equal treatment as proportionate representation (or as a requirement of a fair distribution of social goods among different groups of the population) - rather than simply as a requirement of non-discrimination may not be reconciled with an absolute prohibition of processing data relating to the characteristics which define these different groups. Indeed, such an absolute prohibition would not allow even to gain a clear understanding of the access different segments of the populations have to the scarce social goods (housing, education, employment, health care) which are to be fairly distributed along those groups - let alone, to act in order to remedy any imbalances which could be identified. This is what both the Council of Europe's European Commission against Racism and Intolerance (ECRI) and the Advisory Committee created under the 1995 Council of Europe Framework Convention for the Protection of National Minorities

${ }^{4}$ On the distinction between affirmative action and positive action more generally, see infra, s.4.1. 
seem to recognize, when these bodies insist on the need for States to dispose of precise data as to the situation of minority groups, in order to combat discrimination more effectively. ${ }^{5}$

We are left, then, with three models. Under a first model, discrimination is prohibited, but there is no obligation to ensure a proportionate representation of the diverse social groups whose members are protected from discrimination. Nor is there an effort to monitor the situation of these groups with respect to the global allocation of social goods in order, if necessary, to take remedial action where imbalances are found to exist. Such imbalances as such are not seen as problematic, as long as each individual has not been discriminated against in identifiable ways, by particular agents. Under a second model, the prohibition of discrimination extends to the prohibition of disparate impact discrimination: any measure which disproportionately and negatively impacts upon certain groups which are already underrepresented (or which already receive a less-than-proportionate share of the social good to be allocated), should be revised, unless it can be demonstrated that such measure, although presumptively suspect, aims to realize a legitimate objective by means which are both appropriate and necessary. Under a third model, that of affirmative equality, the aim of ensuring equal treatment is not only to avoid instances of discrimination, but also to make progress towards a fair share of social goods among the different segments of the population. Under this model, affirmative policies are pursued which seek to improve the representation of certain groups in the areas or at the levels where they are underrepresented, and to arrive not only at a situation where discriminatory rules, policies or practices are outlawed, but where, moreover, social goods are distributed more equitably between the diverse groups composing society. Indeed, as clearly illustrated by the debate concerning the admissibility of affirmative action policies, still sometimes referred to as "reverse" or "positive" discrimination, the objective pursued under the model of affirmative equality may conflict with the objective of non-discrimination: where the application of neutral rules or procedures does not fulfil the objective of ensuring a fair distribution of social goods among different groups of the population, it will be required to make further steps towards the full realization of equality; and this may imply treating differently individuals because of their membership in certain groups defined by "suspect" characteristics they present.

It is the thesis of this article that although European anti-discrimination law belongs to the first model of equality described, the Member States are not prohibited from espousing the second model - and, indeed, they should be incentivized to do so. As to the third model of equality, certain obstacles remain. These obstacles relate both to the uncertainties concerning the

5 For the views of the ECRI, see the Third report on Hungary, 5 December 2003, CRI (2004) 25, para.93 and Third report on the Czech Republic, 5 December 2003 , CRI (2004) 22, para.86; see also ECRI General Policy Recommendation No.1 on combating racism, xenophobia, anti-Semitism and intolerance, 4 October 1996 CRI (96) 43 rev For the views of the Advisory Committee of the Framework Convention (ACFC), see the Opinion on Slovakia, 22 September 2000, ACFC/OP/I(2000)001, para.21; Opinion on Croatia, 6 April 2001 , ACFC/OP/I(2002)003, para.29; Opinion on the Czech republic, 6 April 2001, ACFC/OP/I(2002)002, para.28. 
protection of the right to respect for private life vis-à-vis the processing of personal data, and to the current understanding of the principle of equal treatment under European Community law. These obstacles coalesce to make it difficult, if not impossible, for the Member States to move towards an understanding of the principle of equal treatment as affirmative equality. The following sections will attempt to demonstrate this by examining three questions. In section 2, I examine the significance of the prohibition of indirect discrimination and the role, in this regard, of the rules on the allocation of the burden of proof in discrimination cases. In section 3, I comment on the rules relating to personal data protection, and their relationship to the different understandings of equality outlined above. In section 4, I discuss the status of positive action in European Community law. By focusing on these questions, I hope to give more flesh to the differences between the three models of equality which could only be briefly outlined in this introductory section. I also hope to convince the reader that European Law could achieve even more than it has to this date. However, in order to move further along the road of equality, a better understanding of the situation of European Law on the map of equality is required. This article should be seen as a contribution in this direction: although at times critical of the current state of European anti-discrimination law, its critical component in my view is less important than, and remains subordinate to, its constructive ambition.

Before examining these three questions, the answers to which may serve to relate any set of legal rules implementing the principle of equal treatment to one of the equality models outlined above, it may be useful to clarify what I am referring to under the notion of "European anti-discrimination law". Between the entry in force of the Treaty of Rome establishing the European Economic Community on January $1^{\text {st }}, 1958$, and the entry into force of the Treaty of Amsterdam on May 1 $1^{\text {st }}, 1999$, the only provisions of the Treaty of Rome explicitly prohibiting discrimination were Article 119 EEC (now Article 141 EC, after revision) and Article 48 EEC (now Article 39 EC, after revision). Both provisions were seen, not primarily as seeking to protect the fundamental right to equality, but rather as contributing to the common market. This is obvious with respect to Article 48 EEC, which prohibited discrimination based on nationality between the nationals of the Member States as part of the right to free movement of workers within the Community. ${ }^{6}$ But as is well known, the insertion of Article 119 in the original Treaty of Rome also was based on economic justifications ${ }^{7}$ : when it decided that it should be recognized a direct effect, the European Court of Justice noted that one of the objectives of this provision was "to avoid a situation in which undertakings established in States which have actually implemented the principle of equal pay suffer a competitive disadvantage in intra-Community competition as compared with undertakings established in States which have not yet eliminated discrimination against women workers

6 This provision stated that the free movement of workers within the Community "shall entail the abolition of any discrimination based on nationality between workers of the Member States as regards employment, remuneration and other conditions of work and employment".

7 See in particular C. Barnard, "The Economic Objectives of Article 119", in Hervey and O'Keeffe (eds.), Sex Equality Law in the European Union (1996), pp.101-141. 
as regards pay". ${ }^{8}$ The more recent developments of European antidiscrimination law, instead, adopt the perspective of fundamental rights, ${ }^{9}$ although of course the dual concerns of contributing to social cohesion and of raising the level of employment also contribute to explain why combating discrimination was made a priority at European level since the late 1990s. ${ }^{10}$ With the Treaty of Amsterdam, Article 13 EC (initially Article 6A) was inserted into the Treaty of Rome, empowering the Council, acting unanimously on a proposal from the Commission and after consulting the European Parliament, to take appropriate action to combat discrimination based on sex, racial or ethnic origin, religion or belief, disability, age or sexual orientation. ${ }^{11}$ Within months following the entry into force of this new legal basis, the Commission presented the Council with the proposals ${ }^{12}$ which - in a context dominated by a sense of urgency after the Freedom Party of Austria was included in the Austrian governmental coalition in October 1999 - led to the adoption, on 29 June 2000, of Council Directive 2000/43/EC implementing the principle of equal treatment between persons irrespective of racial or ethnic origin (hereafter referred to as the "Racial Equality Directive"), ${ }^{13}$ and on 27 November 2000, of Council Directive 2000/78/EC establishing a general framework for equal treatment in

8 Case 43/75, Defrenne v Sabena (No.2), cited above, para.9. The Court added that the provision also "forms part of the social objectives of the Community, which is not merely an economic union, but is at the same time intended, by common action, to ensure social progress and seek the constant improvement of the living and working conditions of their peoples, as emphasised by the Preamble to the Treaty .." (para.10).

9 On this shift, see More, "The Principle of Equal Treatment: From Market Unifier to Fundamental Right?" in Craig and de Búrca (eds.), The Evolution of EU Law (1999), pp.517-543.

10 See, e.g. the 9th Recital of the Preamble to Council Directive 2000/43/EC (infra, $\mathrm{n} .13$ and corresponding text), which states: "Discrimination based on racial or ethnic origin may undermine the achievement of the objectives of the EC Treaty, in particular the attainment of a high level of employment and of social protection, the raising of the standard of living and quality of life, economic and social cohesion and solidarity". A similar justification may be found in the 11th Recital of the Preamble to Council Directive 2000/78/EC. Both Preambles refer also to the Employment Guidelines for 2000 agreed by the European Council at Helsinki on 10 and 11 December 1999, which stress the need to foster a labour market favourable to social integration by formulating a coherent set of policies aimed at combating discrimination against groups such as persons with disability

11 On the adoption of this provision in the Treaty of Amsterdam and its potential, see Flynn, "The Implications of Article 13 EC - After Amsterdam Will Some Forms of Discrimination be More Equal Than Others?" (1999) 36 Common Market L. Rev 1127; Bell, "Anti-Discrimination Law after Amsterdam", in Shaw (ed.), Social Law and Policy in an Evolving European Union (2000), pp.157-170. The Treaty of Nice, which entered into force on February 1st, 2003, added a paragraph to art.13 EC, stating that "when the Council adopts Community incentive measures, excluding any harmonisation of the laws and regulations of the Member States, to support action taken by the Member States in order to contribute to the achievement of the objectives referred to in para.1, it shall act in accordance with the procedure referred to in art.251 [co-decision, requiring only a qualified majority within the Council]".

$12 \mathrm{COM}(99) 564$ to 566.

13 OJ L 180 of 19.7.2000, p.22. 
employment and occupation ("Employment Equality Directive"). ${ }^{14}$ The Racial Equality Directive imposes on the Member States to prohibit direct and indirect discrimination on grounds of race or ethnic origin, including harassment and the instruction to discriminate, in a large range of situations, comprising not only access to employed and self-employed activities but also areas such as education, social protection including social security and healthcare, social advantages and access to and supply of goods and services. The Employment or "Framework" Equality Directive, is broader with respect to the range of prohibited grounds, yet narrower in its scope of application ratione materiae: it prohibits all forms of direct or indirect discrimination (including, with regard to persons with disabilities, a refusal to provide reasonable accommodation) on the grounds of religion or belief, disability, age or sexual orientation in employment and occupation. The adoption of these legal instruments was complemented by a Decision 2000/750/EC establishing a Community action programme to combat discrimination $(2001-2006) \cdot{ }^{15}$

Soon thereafter, Directive 76/207/EEC on the implementation of the principle of equal treatment for men and women as regards access to employment, vocational training and promotion, and working conditions ${ }^{16}$ was amended by Directive 2002/73/EC of the European Parliament and of the Council of 23 September 2002. ${ }^{17}$ Adopted at a time when Article 119 EEC only stipulated the principle of equal pay between men and women for the same work, the original Directive was based on a legal basis which relates to the establishment or functioning of the common market; ${ }^{18}$ Directive 2002/73/EC is adopted on the basis of Article 141(3) EC, which now provides that the Council may adopt measures to ensure the application of the principle of equal opportunities and equal treatment of men and women in matters of employment and occupation generally. More recently, acting this time on the basis of Article 13 EC (as Article 141 EC only relates to equal treatment between men and women in employment and occupation), the Council adopted Directive 2004/113/EC implementing the principle of equal treatment between men and women in the access to and supply of goods and services on 13 December 2004. ${ }^{19}$ These Directives closely mirror the Racial Equality Directive and the Employment Equality Directive, from which they borrow their concepts and tools. ${ }^{20}$ This is the case, in particular, with regard to the definitions of direct and indirect discrimination, to a number of procedural provisions relating, inter alia, to the protection from reprisals or to the role of associations or organisations which have an interest

OJ L 303 of 2.12.2000, p.16.

15 OJ L 303 of 2.12 .2000$, p.23.

6 OJ L 39 of 14.2.1976, p.40.

17 OJ L 269 of 5.10.2002, p.15.

18 Art.100 EEC (now art.94 EC) allows for the adoption by a unanimous Council of directives for the approximation of the laws, regulations or administrative provisions of the Member States which directly affect the establishment or functioning of the common market.

19 OJ L 373 of 21.12.2004, p.37.

20 This is not to say that the Racial Equality and Employment Equality Directives have always been innovating. On the contrary, many of the provisions of those directives are directly borrowed from the case-law developed by the European Court of Justice in gender equality cases. 
in the enforcement of the provisions of the directives, or to the authorisation of positive action.

It is this set of treaty provisions and legislative instruments, and the case-law which has interpreted them, which I shall be referring to under the notion of "European anti-discrimination law". Of course, the contribution of European Community Law to implementing the principle of equal treatment may not be reduced to this acquis. In particular, the principle of equality has been included by the European Court of Justice among the general principles of law, which it seeks to ensure the respect of in the field of application of Union law. ${ }^{21}$ Indeed, in situations to which any of the above-mentioned directives would be applicable, but which also concern a measure adopted by a Member State which falls under the scope of application of Union law (for example because that measure seeks to implement a directive, or brings an exception to a fundamental freedom recognized under European Community law), it may be preferable to rely on the general principle of equality as a fundamental right, rather than on the applicable directive, because directives only may be directly invoked against public authorities and not "horizontally", against private individuals. ${ }^{22}$ In the context of this article, however, we need not concern ourselves with the general principle of equality as developed in the case-law of the European Court of Justice. This article seeks to locate the choices made by the European legislator in the broader framework of anti-discrimination law. It is not its intention to offer a complete picture of the contribution of European Union law to combating discrimination.

\section{The Dual Purpose of Prohibiting Indirect Discrimination}

Indirect discrimination consists in the application of regulations, criterions or practices, which although apparently neutral, will produce an effect similar to the use of a prohibited ground of distinction: for instance, by paying lower hourly wages to part-time workers than what full-time workers would receive for the same work, in a situation where the part-time workforce is overwhelmingly female, the result achieved is similar to that of a pay policy which would pay women less than men, in violation of Article 141(1) EC. The prohibition of indirect discrimination is therefore the inevitable

21 Case C-144/04, Mangold v Helm, nyr (judgment of 22 November 2005 delivered upon a request for a preliminary ruling under art.234 EC from the Arbeitsgericht München (Germany)), at paras.74-75 (noting that "Directive 2000/78 does not itself lay down the principle of equal treatment in the field of employment and occupation (. . .) the source of the actual principle underlying the prohibition of those forms of discrimination being found (. . .) in various international instruments and in the constitutional traditions common to the Member States"). See also, among many others, Case C-442/00, Caballero [2002] ECR I-11915, paras.30 to 32; Case C-13/94, P. v S. and Cornwall City Council [1996] ECR I2143, paras.18 and 19 (describing Directive 76/207/EEC as an expression of the principle of equality as a fundamental principle of law and recalling that the right not to be discriminated against on grounds of sex is a fundamental human right protected by the Court); Joined Cases 201/85 and 202/85, Klensch [1986] ECR 3477, paras.9 to 10; Case 149/77, Defrenne v Sabena (No.3) [1978] ECR 1365, paras.26-27.

22 See the Opinion of Advocate General Tizzano delivered in the case of Mangold, supra $\mathrm{n} .21$, at para.84. 
complement to the prohibition of direct discrimination which, otherwise, would be easily circumvented. However, behind this simple definition, two quite different conceptions of the function of indirect discrimination coexist. $^{23}$ Under a first conception, which explains best the origins of the concept, the prohibition of indirect discrimination serves to unmask instances of intentional discrimination which seek to achieve indirectly what may not be done directly. Under another conception, it is completely detached from any kind of intention to discriminate, and is best seen as a tool to permanently revise institutionalized habits and procedures, in order to make them more hospitable to difference. While the first objective (unmasking instances of wilful discrimination which hide behind the use of apparently neutral measures) may be served either through the use of statistics in order to demonstrate the impact of those measures or through the concept of "apparently neutral, but suspect, measures", the second objective (adapting the structures to accommodate difference) necessarily requires the use of statistical tool, as the concept of indirect discrimination is extended to cover instances of disparate impact discrimination.

\subsection{Indirect discrimination as disparate impact discrimination}

The case of Jenkins ${ }^{24}$ was the first in which the European Court of Justice included a prohibition of indirect discrimination in its case law. The referring court, the United Kingdom Employment Appeal Tribunal, sought to know whether a difference in the level of pay for work carried out part-time and the same work carried out full-time may amount to discrimination of a kind prohibited by Article 119 EEC when the category of part-time workers is exclusively or predominantly comprised of women. In its judgment of 31 March 1981, the European Court of Justice answered that this situation was not discriminatory "in so far as the difference in pay between part-time and full-time work is attributable to factors which are objectively justified and are in no way related to any discrimination based on sex", ${ }^{25}$ for example where, by such pay policy, "the employer is endeavouring, on economic grounds, to encourage full-time work irrespective of the sex of the worker". ${ }^{26}$ It added however that it should be considered a form of discrimination "where, regard being had to the difficulties encountered by women in arranging to work that minimum number of hours per week, the pay policy of the undertaking in question cannot be explained by factors other than discrimination based on sex". ${ }^{27}$ The notion of indirect discrimination, here, still is conceived as a means to prohibit intentional discrimination, where a pay policy is devised in order to achieve indirectly what may not be done overtly, by the use of sex as a criterion for calculating wages: the national courts should decide in each individual case "whether, regard being had to the facts of the case, its history and the employer's intention, a pay policy [where the hourly rate of pay differs according to whether the work is part-

23 For a more detailed discussion, De Schutter, Discriminations et marché du travail. Liberté et égalité dans les rapports d'emploi (2000) 93-144.

24 Case 96/80, J.P. Jenkins v Kingsgate (Clothing Productions) Ltd. [1981] ECR 911 (judgment of 31 March 1981).

25 Para.11.

26 Para.12.

27 Para.13. 
time or full-time] although represented as a difference based on weekly working hours is or is not in reality discrimination based on the sex of the worker". ${ }^{28}$

In Bilka-Kaufhaus, decided five years later, the approach already has shifted. ${ }^{29}$ The European Court of Justice considers in that case that under Article 119 EEC, an employer may justify the adoption of a pay policy excluding part-time workers from its occupational pension scheme, irrespective of their sex, on the ground that it seeks to employ as few parttime workers as possible, "where it is found that the means chosen for achieving that objective correspond to a real need on the part of the undertaking, are appropriate with a view to achieving the objective in question and are necessary to that end". ${ }^{30}$ The importance of Bilka-Kaufhaus resides in the explicit admission by the Court that, once it is shown that the pay policy has a disparate impact on women (which are over-represented within the part-time workers), ${ }^{31}$ the burden of proof lies on the employer to demonstrate that the policy has economic justifications which satisfy the requirements of appropriateness and necessity. It is not for the part-time female employee to demonstrate that the exclusion of part-time workers from the occupational pension scheme is the means chosen by the employer to discriminate against women; it is for the employer to demonstrate the economic necessity of such exclusion, once a disparate impact on women is identified.

The adoption on 15 December 1997 of Council Directive 97/80/EC on the burden of proof in cases of discrimination based on $\operatorname{sex}^{32}$ may be seen as the natural outcome of this line of cases. ${ }^{33}$ The Directive is based on the finding

28 Para.14 (emphasis added). The European Court of Justice concludes that "a difference in pay between full-time workers and part-time workers does not amount to discrimination prohibited by Article 119 of the Treaty unless it is in reality merely an indirect way of reducing the level of pay of part-time workers on the ground that that group of workers is composed exclusively or predominantly of women" (para.15). The language used clearly indicates that the notion of indirect discrimination is merely invoked here to prohibit the employer from circumventing the prohibition of direct discrimination against women or men in remuneration.

29 Case 170/84, Bilka - Kaufhaus GmbH v Karin Weber von Hartz, [1986] ECR 1607 (judgment of 13 May 1986).

30 Para.37.

31 According to the data provided to the European Court of Justice by the referring court, $10 \%$ of the full-time workforce (benefiting thus from the occupational pensions scheme) was female; altogether, the undertaking comprised $72 \%$ of men and $28 \%$ of women; $90 \%$ of the men were employed on a full-time basis $(10 \%$ on a part-time basis); $61,5 \%$ of the women were working full-time (38,5\% part-time).

32 OJ L 14 of 20.1.1998, p.6.

33 See, among many others, Case 171/88, Rinner-Kühn [1989] ECR 2743 (para.12) (judgment of 13 July 1989); Case C-33/89, Kowalska [1990] ECR I2591 (para.16) (judgment of 27 June 1990); Case C-184/89, H. Nimz [1991] ECR I-297 (para.12) (judgment of 7 February 1991); Case C-127/92, Enderby [1993] ECR I-5535 (para.17) (judgment of 27 October 1993); Case C-444/93, Megner and Scheffel v Innungskrankenkasse Rheinhessen-Pfalz [1995] ECR I-4741 (para.24); Case C-343/92, De Weerd (née Roks) and Others [1994] ECR I-571 
that, although the European Court of Justice has held that the rules on the burden of proof must be adapted when there is a prima facie case of discrimination and that, for the principle of equal treatment to be applied effectively, the burden of proof must shift back to the respondent when evidence of such discrimination is brought, not all the Member States have adapted their rules on the burden of proof in discrimination cases accordingly. ${ }^{34}$ The Directive defines indirect discrimination as a situation where "an apparently neutral provision, criterion or practice disadvantages a substantially higher proportion of the members of one sex unless that provision, criterion or practice is appropriate and necessary and can be justified by objective factors unrelated to sex". ${ }^{35}$ It provides that, "when persons who consider themselves wronged because the principle of equal treatment has not been applied to them establish, before a court or other competent authority, facts from which it may be presumed that there has been direct or indirect discrimination, it shall be for the respondent to prove that there has been no breach of the principle of equal treatment". ${ }^{36}$

This approach to the concept of indirect discrimination, understood as the discrimination which results from the disparate impact of certain apparently neutral provisions, presents one advantage and one difficulty. Its advantage is in the breadth of its potential reach. Indirect discrimination, under this approach, may be identified even in measures whose content, as such, is not in any way suspect. Wherever a particular measure produces a disparate impact on the members of certain protected categories, it will have to be justified, even where that measure, apart from this statistically proven impact, would not appear to be potentially discriminatory. This advantage is clear especially in situations where the challenged practices is opaque or informal, thus making it difficult to anticipate its impact. In Danfoss for instance, as the undertaking had a pay policy which was characterized by a total lack of transparency, the Court of Justice considered that "it is for the employer to prove that his practice in the matter of wages is not discriminatory, if a female worker establishes, in relation to a relatively large number of employees, that the average pay for women is less than that for men". ${ }^{37}$ A similar reasoning could be made where an employer bases a recruitment process on the use of criterions or procedures which either are opaque (for instance, psychotechnical tests or job interviews), or more generally, whose potentially discriminatory impacts may only be identified by the use of statistics (for instance, where preference is given to candidates residing in a particular geographical area, where certain ethnic minorities are located primarily in other neighbourhoods and are thus disproportionately affected by the use of such a criterion).

The disadvantage of this method however, is that it requires the reliance on a specific methodology, based on the collection and analysis of statistical data,

(para.33); Case C-100/95, Kording [1997] ECR I-5289 (para.18) (judgment of 2 October 1997).

34 See the Preamble, Recitals 18-20.

35 Article 2(2) of Directive 97/80.

36 Article 4(1) of Directive 97/80.

37 Case 109/88, Handels- og Kontorfunktionarernes Forbund I Danmark v Dansk Arbejdsgiverforening, acting on behalf of Danfoss [1989] ECR 3199 (judgment of 17 October 1989), para.16. 
which may be particularly burdensome or even unavailable to victims of discrimination. Disparate impact analysis requires a comparison between the representation of different categories of persons (say, women and men, or different ethnic groups) within a "departure group" and their representation in the "arrival group", after an apparently neutral measure has been applied: the existence of a discrimination shall be presumed where the impact of that measure appears "disproportionate", that is, where the representation of one category (say, women, or persons of a certain ethnic origin) is significantly lower in the "group of arrival" than in the "departure group". However, apart from the question of what constitutes a disproportionate impact for the purposes of this analysis, the implementation of such a methodology requires that we define with precision the boundaries of the "departure group" on the basis of which the impact of the provision, criterion or practice may be calculated. In the context of employment for instance, the delimitation of the "departure group" raises questions such as that of which minimum level of qualifications may be required in order to delineate the "pool" of candidates to a job between whom the selection is to be made ${ }^{38}$ - unless the job offered requires no qualifications or only minimal qualifications, or may be acquired by the training which the employer will provide ${ }^{39}$ - or what role we allow the "preferences" expressed by potential applicants to play - although we know, of course, that such "preferences" are always suspect of being tainted by the existence of institutional discrimination or, indeed, by the very fact of under-

${ }^{38}$ Thus for instance, it would not be justified to presume that a recruitment process is indirectly discriminatory where, although only $10 \%$ of workers are of a certain ethnic origin in a region where $25 \%$ of the active population is of that ethnic group, only $5 \%$ of those having completed their secondary education are members of that group. If we consider that having completed high school is an essential requirement for being employed in the undertaking concerned (more plausibly: within a particular occupation in that undertaking), the recruitment process is in fact favourable to persons of that ethnic group, although they still are underrepresented in that undertaking in comparison to their representation in the overall active population of the area. See, e.g. for situations where the definition of the relevant "pool" has been discussed within the case-law of the United States Supreme Court, in the context of Title VII of the Civil Rights Act 1964: Johnson v Transportation Agency, Santa Clara County, Calif., et al., 107 S. Ct. 1442, 1452 (1987) ("When a job requires special training [...] the comparison should be with those in the labour force who possess the relevant qualifications"); Mayor of Philadelphia v Educational Equality League, 415 U.S. 605, 620 (1974) (noting that the Court is not dealing with a situation where "it can be assumed that all citizens are fungible for purposes of determining whether members of a particular class have been unlawfully excluded"); Hazelwood School District v United States, 433 U.S. 299 (1977) (in order to address the allegation that a procedure for the recruitment of schoolteachers is indirectly discriminatory on the basis of race, the percentage of blacks schoolteachers recruited in a particular county should be compared with "the percentage of qualified black teachers in are labour force"); City of Richmond $\mathrm{v}$ J.A. Croson Co., 488 U.S. 469 (1989) ("where special qualifications are necessary, the relevant statistical pool for purposes of demonstrating discriminatory exclusion must be the number of minorities qualified to undertake the particular task").

${ }^{39}$ See, e.g. Teamsters v United States, 431 U.S. 324 (1977); United Steelworkers of America v Weber, 443 U.S. 193 (1979) (stating that it should be put an end to the affirmative action programme set up within the undertaking for access to training "as soon as the percentage of black skilled craftworkers in the [. . .] plant approximates the percentage of blacks in the local labour force"). 
representation of certain groups within certain sectors or at certain levels of the professional ladder. ${ }^{40}$ Moreover, the assessment of the impact of such measure requires that we define the representation of the different categories within both the "departure group" and the "arrival group" where, in many cases, such data may be inexistent or where there may even be legal obstacles to the collection of such data. ${ }^{41}$

\subsection{Indirect discrimination and the inherently suspect measure}

Article 2(2)(b) of the Racial Equality and Employment Equality Directives state that indirect discrimination "shall be taken to occur where an apparently neutral provision, criterion or practice would put persons [to whom the protected grounds apply] at a particular disadvantage compared with other persons, unless that provision, criterion or practice is objectively justified by a legitimate aim and the means of achieving that aim are appropriate and necessary". Both directives also provide for the shifting of the burden of proof in discrimination cases: "when persons who consider themselves wronged because the principle of equal treatment has not been applied to them establish, before a court or other competent authority, facts from which it may be presumed that there has been direct or indirect discrimination, it shall be for the respondent to prove that there has been no breach of the principle of equal treatment". ${ }^{42}$ The facts from which it may be inferred that there has been a direct or indirect discrimination are to be left to the appreciation of national judicial or other competent bodies, in accordance with rules of national law or practice. The Preambles to the Directives add that these national rules "may provide in particular for indirect discrimination to be established by any means including on the basis of statistical evidence". ${ }^{43}$

These directives therefore rely on a concept of indirect discrimination which differs from the concept emerging from the case-law of the European Court of Justice in equal treatment between men and women cases and codified in Directive 97/80/EC on the burden of proof in cases of discrimination based on sex. ${ }^{44}$ Rather than seeking to take into account that certain measures,

40 Thus, the low level of representation of ethnic minorities in certain positions may discourage them from seeking to attain the educational level which would give them access to those positions, as emphasized in the "human capital formation" concept of Gary Becker (G. Becker, "Investment to Human Capital: A Theoretical Analysis", Journ. Pol. Econ., vol. LXX (No. 5, part 2), October 1962, pp.9-49; Becker, The Human Capital: A Theoretical Approach and Empirical Analysis With Special Reference to Education (1st ed. 1964)). Similarly, the existence of racism or sexism in certain professional environments may discourage women or minorities from seeking to enter into those milieus: see, e.g. Anker, "Ségrégation professionnelle hommes-femmes: les théories en présence", Rev int. du travail, vol.136, No.3, 1997, p.343, at p.345.

41 I return to this question in section 3.

42 Art.8(1) of the Racial Equality Directive; art.10(1) of the Employment Equality Directive.

43 15th Recital of the Preamble.

44 Although the definition of indirect discrimination provided in the Racial Equality and Employment Equality Directives has now been replicated in Directive $76 / 207 / \mathrm{EEC}$ as amended in 2002 (see art.2(2) of Directive 76/207/EEC, as amended by art.1(2) of Directive 2002/73/EC of 23 September 2002) and in 
despite being apparently neutral, may have a disparate impact on certain protected categories - which, if such impact is proven by statistical means, will require that they be justified as appropriate and necessary for the achievement of certain legitimate aims - the Racial Equality and Employment Equality Directives are based on the idea that certain apparently neutral measures in fact may be seen as inherently suspect, because although not explicitly differentiating on the basis of a suspect ground, they may be seen as imposing a particular disadvantage on certain protected categories.

This betrays the original intent of the Commission as expressed in the antidiscrimination package it presented on 25 November 1999. ${ }^{45}$ When, in these initial proposals, the Commission put forward a definition of indirect discrimination inspired by the case-law of the European Court of Justice in the area of free movement of workers, it intended this competing definition to facilitate the task of the victim in proving discrimination, without limiting the potential reach of the prohibition. According to this alternative definition: "indirect discrimination shall be taken to occur where an apparently neutral provision, criterion or practice is liable to affect adversely a person or persons to whom [a suspect ground] applies, unless that provision, criterion or practice is objectively justified by a legitimate aim and the means of achieving it are appropriate and necessary". As clearly illustrated by the very judgment of the European Court of Justice referred to by the Commission, under this alternative definition of indirect discrimination, the victim is not obliged to collect statistical data, which will often be unavailable or will be considered valid only if the representative sample is important enough. ${ }^{46}$ However, the Commission intended that the

Directive 2004/113/EC of 13 December 2004 implementing the principle of equal treatment between men and women in the access to and supply of goods and services (see art.2(b) of Directive 2004/113/EC), Council Directive 97/80/EC on the burden of proof in cases of discrimination based on sex (supra, n.32) remains in force; therefore, notwithstanding the new definition of indirect discrimination in Directive 76/207/EEC, disparate impact discrimination still is prohibited when based on sex.

45 Supra, n.12.

46 See Case C-237/94, O'Flynn v Adjudication Officer [1996] ECR 2417 (judgment of 23 May 1996). Mr O'Flynn, an Irish national residing in the United Kingdom whose son had deceased, had been refused a funeral payment under the United Kingdom Social Fund (Maternity and Funeral Expenses) Regulations 1987, because of a territorial provision in those Regulations stipulating that a funeral payment were to be made only if "the funeral takes place within the United Kingdom". The Court concluded that this condition was in breach of art.7(2) of Regulation (EEC) No 1612/68 of the Council of 15 October 1968 on freedom of movement for workers within the Community (OJ, English Special Edition 1968 (II), p.475), under which a worker from one Member State is to enjoy in the territory of the other Member States the same social and tax advantages as national workers. It recalled its case-law according to which "conditions imposed by national law must be regarded as indirectly discriminatory where, although applicable irrespective of nationality, they affect essentially migrant workers (see Case 41/84, Pinna v Caisse d'Allocations Familiales de la Savoie [1986] ECR 1, para.24; Case 33/88, Allué and Another v Università degli Studi di Venezia [1989] ECR 1591, para.12; and Le Manoir, para.11) or the great majority of those affected are migrant workers (see, Case C-279/89, Commission v United Kingdom [1992] ECR I-5785, para.42, and Case C-272/92, Spotti v Freistaat Bayern [1993] 
victim should retain the option to prove discrimination by statistical means, even if this is not required to shift the burden of proof on the shoulders of the defendant. The proposal of the Commission for a Council Directive establishing a general framework for equal treatment in employment and occupation explains that:

"In the field of sex discrimination, the European Court of Justice has required statistical evidence to prove indirect discrimination. However, adequate statistics are not always available. For example, there may be too few persons in a firm who are affected by the provision in question or where the provision, criterion or practice has just been introduced, statistics may not yet be available. (. . .) According to [the definition of indirect discrimination proposed by the Commission $^{47}$ ], an apparently neutral provision, criterion or practice will be regarded as indirectly discriminatory if it is intrinsically liable to adversely affect a person or persons on the grounds referred in Article 1. The 'liability test' may be proven on the basis of statistical evidence or by any other means that demonstrate that a provision would be intrinsically disadvantageous for the person or persons concerned." ${ }^{48}$

It is clear from the last sentence that the Commission intended to allow for victims of discrimination to present statistical data in order to establish a presumption of discrimination, shifting the burden of proof to the defendant. Instead, as a result of the discussions within the Council, the Member States now have the choice whether or not to allow victims to rely on statistics in

ECR I-5185, para.18), where they are indistinctly applicable but can more easily be satisfied by national workers than by migrant workers (see Commission $\mathrm{v}$ Luxembourg, para.10, and Case C-349/87, Paraschi $\mathrm{v}$ Landesversicherungsanstalt Wuerttemberg [1991] ECR I-4501, para.23) or where there is a risk that they may operate to the particular detriment of migrant workers (see Case C-175/88, Biehl v Administration des Contributions [1990] ECR I-1779, para.14, and Case C204/90, Bachmann v Belgium [1992] ECR I-249, para.9)" (para.18), unless "those provisions are justified by objective considerations independent of the nationality of the workers concerned, and if they are proportionate to the legitimate aim pursued by the national law (see, to that effect, Bachmann, para.27; Commission v Luxembourg, para.12; and Joined Cases C-259/91, C-331/91 and C-332/91 Allué and Others v Università degli Studi di Venezia [1993] ECR I-4309, para.15)" (para.19). In sum, said the Court: "unless objectively justified and proportionate to its aim, a provision of national law must be regarded as indirectly discriminatory if it is intrinsically liable to affect migrant workers more than national workers and if there is a consequent risk that it will place the former at a particular disadvantage. It is not necessary in this respect to find that the provision in question does in practice affect a substantially higher proportion of migrant workers. It is sufficient that it is liable to have such an effect (. . .)" (paras.20-21 (emphasis added)).

47 In its initial version, the definition read: "indirect discrimination shall be taken to occur where an apparently neutral provision, criterion or practice is liable to affect adversely a person or persons to whom any of the grounds [referred to in the directive] applies, unless that provision, criterion or practice is objectively justified by a legitimate aim and the means of achieving it are appropriate and necessary".

48 COM(1999) 565 final, 25.11.1999, at p.8 (emphasis added). 
order to establish a presumption of discrimination. ${ }^{49}$ As a result, in a number of Member States where this option will not be open to victims, it will not be possible to impose on the author of an apparently neutral measure to justify that this measure is both appropriate and necessary for a legitimate objective, even in a situation where a disparate impact of that measure on a certain protected category may occur, unless the victim may convince the competent authority that the challenged measure would put the members of that category "at a particular disadvantage compared with other persons".

This significantly narrows the reach of the principle of equal treatment. By way of illustration, consider the well-known case of Griggs v Duke Power Co., which the United States Supreme Court decided in 1971 and which is generally seen as the first "disparate impact" decision adopted under the Employment Title (Title VII) of the Civil Rights Act 1964. ${ }^{50}$ This class action, filed on behalf of the African-American employees of the Duke Power Company, challenged the defendant's "inside" transfer policy, which required employees who wanted to work in all but the company's lowest paying Labour Department to register a minimum score on two separate aptitude tests in addition to having a high school education. The Court considered that this policy was in violation of the applicable provision of the Civil Rights Act. ${ }^{51}$ There was evidence that, under this policy, far more Whites would accede to the other departments than African-Americans: in North Carolina, 1960 census statistics showed that, while $34 \%$ of white males had completed high school, only $12 \%$ of African-American males had done so; and with respect to standardized tests, the Employment Equal Opportunities Commission (EEOC) had found that use of a battery of tests, including the Wonderlic and Bennett tests used by the Company in the instant case, resulted in $58 \%$ of whites passing the tests, as compared with only $6 \%$ of the blacks. ${ }^{52}$ This prompted the Court to ask whether the requirements were justified by "business necessity" - for, as recalled by the Court, the Civil Rights Act "proscribes not only overt discrimination but also practices that are fair in form, but discriminatory in operation. The touchstone is business necessity. If an employment practice which operates to exclude Negroes cannot be shown to be related to job performance, the practice is prohibited". Insofar as "neither the high school completion

49 See supra, text corresponding to n.43.

50 Griggs v Duke Power Co., 410 U.S. 424 (1971). On the significance of this case, see D.A. Strauss, "Discriminatory Intent and the Taming of Brown", 56 Univ Chicago L. Rev 935 (1989); or Th. Eisenberg, "Disproportionate Impact and Illicit Motive: Theories of Constitutional Adjudication", 52 N.Y.U. L. Rev 36 (1977).

51 At the material time, Sec. 703 of the Civil Rights Act 1964 provided that "(a) It shall be an unlawful employment practice for an employer ... (2) to limit, segregate, or classify his employees in any way which would deprive or tend to deprive any individual of employment opportunities or otherwise adversely affect his status as an employee, because of such individual's race, colour, religion, sex, or national origin. . . (h) Notwithstanding any other provision of this title, it shall not be an unlawful employment practice for an employer . . . to give and to act upon the results of any professionally developed ability test provided that such test, its administration or action upon the results is not designed, intended or used to discriminate because of race, colour, religion, sex or national origin. . . " (78 Stat. 255, 42 U.S.C. 2000e-2).

52 See the references in n.6 of the Griggs majority opinion. 
requirement nor the general intelligence test is shown to bear a demonstrable relationship to successful performance of the jobs for which it was used", the Court concluded that the policy was discriminatory:

"The facts of this case demonstrate the inadequacy of broad and general testing devices as well as the infirmity of using diplomas or degrees as fixed measures of capability. History is filled with examples of men and women who rendered highly effective performance without the conventional badges of accomplishment in terms of certificates, diplomas, or degrees. Diplomas and tests are useful servants, but Congress has mandated the commonsense proposition that they are not to become masters of reality."

The point to be emphasized here is that, without data indicating the percentage of African-Americans and Whites respectively having completed high school in North Carolina, and indicating the disproportionate impact of so-called "aptitude tests" on African-American applicants, these practices would not have been considered suspect and presumptively discriminatory. In fact, without breaking down the workforce of the Duke Power Company into ethnic groups, those requirements would most probably have gone unnoticed: even though upon closer examination they may have been found to impose disproportionate requirements on applicants, they would not appear, on their face at least, to impose a particular disadvantage on the African-American workers.

The lesson from Griggs is clear. By dropping the requirement that the Member States allow alleged victims of discriminations to shift the burden of proof on the defendant when statistics indicate that an apparently neutral provision, criterion or practice has produced a disparate impact on certain protected categories, it is the specific form of indirect discrimination outlawed in Griggs - disparate impact discrimination - that the European legislator has made difficult, or even impossible in practice, to challenge. Indeed, part of the difficulty with the requirement that the apparently neutral measure be shown to impose a "particular disadvantage" on the protected category, is that such a definition of indirect discrimination remains implicitly indebted to an understanding of discrimination which sees it as necessarily intentional. When it was decided in 1971, Griggs opened a parenthesis in the case-law of the United States federal courts during which the prohibition of discrimination was completely detached from the intent to discriminate: the simple fact of disparate impact, even if resulting from measures adopted in good faith, will suffice to require a justification from the author of the measure having that impact. ${ }^{53}$

53 A few years after Griggs, the United States Supreme Court decided that, under the Equal Protection Clause of the 14th Amendment to the Constitution, "the invidious quality of a law claimed to be racially discriminatory must ultimately be traced to a racially discriminatory purpose" (Washington v Davis, 426 U.S. 229 (1976)). See also, to the same effect, Village of Arlington Heights v Metropolitan Housing Development Corp., 429 U.S. 252, 265 (1977); Personnel Administrator of Massachussetts v Feeney, 442 U.S. 256 (1979); Hunter v Underwood, 471 U.S. 222 (1985). Under Title VII of the Civil Rights Act 1964, Griggs v Duke Power Co. was decisively overturned by Wards Cove Packing Co. v Antonio, 490 U.S. 
Apart from narrowing the scope of the principle of equal treatment, the requirement imposed on the alleged victim of an indirect discrimination resulting from the application of an apparently neutral measure to demonstrate that such application may put the members of a protected category "at a particular disadvantage compared with other persons" may give rise to specific difficulties. First, where the addressees of a provision or those to whom a criterion is being applied or who are affected by a practice could have avoided being put at a particular disadvantage compared to other persons by adopting a certain behaviour (for instance, by acquiring a particular qualification required by the employer, by sacrificing a specific dimension of one's ethnicity or by renouncing one aspect of one's freedom to express a religious belief), the question arises whether they may they still complain about a measure which creates this disadvantage. It is clear that, where the change in behaviour would imply abandoning one of the traits by which an ethnic or religious minority defines itself, it would be unacceptable to reject a discrimination claim on the ground that, by not "adapting" to the challenged requirement, the victim would have waived his or her right to complain. $^{54}$ Certain borderline cases may emerge, however, where a specific practice is not central to one's ethnicity or religion.

642, 109 S.Ct. 2115 (1989). Under Wards Cove Packing Co., it is not enough for the applicant to identify "a racial imbalance in the workforce"; he or she must "isolate and identify the specific employment practices that are allegedly responsible for any observed statistical disparities". Moreover, the decision stated that the practice challenged because of its disparate impact should not necessarily be proven by the respondent to be "essential" or "indispensable" to the employer's business: "The touchstone of the inquiry", says the Court, "is a reasoned review of the employer's justification for his use of the challenged practice". The federal Congress reacted by adopting the Civil Rights Act 1991 (Pub. L. No. 102-66, 105 Stat. 1071), restricting the reach of the Wards Cove Packing Co. doctrine. As amended, the relevant provision of the Civil Rights Act now states that "(1) (A) An unlawful employment practice based on disparate impact is established under this subchapter only if - (i) a complaining party demonstrates that a respondent uses a particular employment practice that causes a disparate impact on the basis of race, colour, religion, sex, or national origin and the respondent fails to demonstrate that the challenged practice is job related for the position in question and consistent with business necessity; or (ii) the complaining party makes the demonstration (. . . ) with respect to an alternative employment practice and the respondent refuses to adopt such alternative employment practice. (B) (i) With respect to demonstrating that a particular employment practice causes a disparate impact as described in subparagraph (A)(i), the complaining party shall demonstrate that each particular challenged employment practice causes a disparate impact, except that if the complaining party can demonstrate to the court that the elements of a respondent's decision-making process are not capable of separation for analysis, the decision-making process may be analyzed as one employment practice. (ii) If the respondent demonstrates that a specific employment practice does not cause the disparate impact, the respondent shall not be required to demonstrate that such practice is required by business necessity" (42 U.S.C. s.2000e-2, (k) - Burden of proof in disparate impact cases). On the intentions behind the Civil Rights Act 1991, see Perritt, Civil Rights Act of 1991: Special Report, New York, John Wiley and Sons, 1992.

54 See, e.g. CRE v Dutton (1989) 1 All ER 306, 315 (where, in a case inn concerning an inn-owner accused of committing discrimination against gypsies under the Race Relations Act 1976, as he had posted a bill denying entrance to travellers, the 
Second, the application of the "particular disadvantage" standard retained under the current definition of indirect discrimination under the Racial Equality and the Employment Equality Directives requires both that all or the vast majority of the members of a group present certain common characteristics, and that these are sufficiently well known. Only through such knowledge will it be possible to screen the apparently neutral provisions, criterions or practices, and thereby to identify measures which could be presented as suspect. Conversely, the greater our ignorance about the average situation of the members of one protected category, the more difficult the task will be of identifying certain measures as "suspect". For instance, it requires a certain understanding of the situation of persons with disabilities to see that a measure setting a maximum age may be imposing a particular disadvantage on those persons (as they generally arrive later on the labour market), or that a requirement that the candidate to a job have a driving license could have this effect. ${ }^{55}$ Similarly, the particular disadvantage resulting for the members of an ethnic minority from the use in a recruitment process of a criterion based on the place of residence requires that we possess information about the geographical segregation of different ethnic groups in a given region; the particular disadvantage on ethnic minorities resulting from recruitment by networks, in particular within the family acquaintances of the employees ${ }^{56}$ also presupposes that we have an idea about the ethnic composition of the existing workforce, which such recruitment processes will tend to perpetuate or reinforce. With respect to certain protected categories, the "particular disadvantage" standard will simply prove useless, as the members of the protected category simply present no other characteristic in common than what makes them members of that category: thus, there exists no "apparently neutral" criterion (with the exception perhaps of a preference in favour of married persons or persons with a family in the traditional sense) which will work to systematically exclude persons with a homosexual sexual orientation; an employer wishing to exclude homosexuals from the workforce will therefore rely on informal means of

Court of Appeal noted: "gipsies can and do cease to be nomadic, but that will be of little use to a particular nomadic gipsy when he chances on the [respondent inn] and wishes to go in for a drink. At that stage he is, in practice, unable to comply"); or Mandla v Dowell Lee (1983) 1 All ER 1062, 1069 ("It is obvious that Sikhs, like anyone else, 'can' refrain from wearing a turban, if 'can' is construed literally. But if the broad cultural/historic meaning of ethnic is the appropriate meaning of the word in the 1976 Act, then a literal reading of the word 'can' could deprive Sikhs and members of other groups defined by reference to their ethnic origins of much of the protection which Parliament evidently intended the 1976 [Race Relations] Act to afford to them. They 'can' comply with almost any requirement or condition if they are willing to give up their distinctive customs and cultural rules [. . .] The word 'can' [. . .] must [. . .] have been intended by Parliament to be read not as meaning 'can physically', so as to indicate a theoretical possibility, but as meaning 'can in practice' or 'can consistently with the customs and cultural conditions of the racial group"').

55 See Waddington, Disability, Employment and the European Community (1995) 56.

56 On this form of recruitment, see Bataille, Le racisme au travail (1997) 122-123; Eymard-Duvernay and Marchal, Façons de recruter. Le jugement des compétences sur le marché du travail (1997), at 26 and 37; Granovetter, Getting a Job. A Study of Contracts and Careers (1974) 46. 
selection, particularly job interviews, the discriminatory impact of which it will be impossible to challenge in the absence of statistical data.

A third difficulty is that the approach the Racial Equality and Employment Equality Directives adopt towards the notion of indirect discrimination simply is not realistic, at least in the context of employment. In the great majority of cases, the evaluation of the candidates competing for a job or for a promotion shall be based on both informal processes (in particular, job interviews) and relatively vague criteria, such as "personality", conformity to the "culture" of the institution, or the "presentation" of the candidate. The evaluation is thus negotiated, rather than planified. ${ }^{57}$ In the face of such informal criteria, it is not particularly helpful for the victim of a discrimination to be authorized to demonstrate that certain provisions, criteria or practices are imposing a "particular disadvantage" to the category to which he or she belongs. Precisely because of the informality of such criteria, these criteria may not be considered as suspect a priori. What matters is not what they look like, but how they are applied in practice: only an a posteriori evaluation of the impact of such criteria being applied, based on a statistical analysis, may succeed in unveiling their discriminatory character, whether the discrimination is conscious or unconscious.

\subsection{Conclusion}

When it proposed the instruments which would become the Racial Equality Directive and the Employment Equality Directive, the Commission had intended the victims to be able to rely on statistical data in order to establish a presumption of discrimination, although it considered that the victims should not be obliged to provide the competent authority with such data where it was sufficiently clear that the challenged measure was liable to affect adversely a person or persons to whom any of the protected grounds applied. ${ }^{58}$ The Council decided instead to leave it to the Member States to decide whether or not they should provide for the possibility for the victim of discrimination to rely on statistics to establish a presumption of indirect discrimination. This implies that, except in the clearest cases where the apparently neutral measure almost may be seen as having been calculated to produce the discriminatory effect which could not be achieved by openly discriminatory measures, the victim will find it difficult or even impossible to shift the burden of proof on the author of the measure, even where this measure has a clearly disparate impact on certain protected groups. This runs counter to what, under most jurisdictions, justified the introduction of the concept of indirect discrimination in the first place. As noted by a comparative study commissioned by the European Commission on the collection of data to measure the extent and impact of discrimination ${ }^{59}$ :

57 For a theoretical discussion of this opposition, see Eymard-Duvernay and Marchal, Façons de recruter, supra n. 56 at 24-26. For empirical evidence, see, inter alia, D. Bartram, P. Lindley, L. Marschall, J. Foster, "The Recruitment and Selection of Young People by Small Businesses", Journ. of Occupational and Organisational Psychology, vol. 68 (1995) 339.

58 See supra, n.47 and the corresponding text.

${ }^{59}$ Comparative Study on the collection of data to measure the extent and impact of discrimination within the United States, Canada, Australia, Great-Britain and the 
"The indirect discrimination concept and the related action schemes, are intrinsically linked to statistics by their logic and objectives. The definition of indirect discrimination is based on quantitative concepts: significant effects and comparisons between groups. The cognitive tools used to capture indirect discrimination, which is the reasoning on which legal and political developments are based, are statistical. The group concept is the focus: treatment is no longer personalised, it is collective and only relates to individuals in terms of their real or assumed affiliation to a protected group. This shift from the individual to a group is strictly analogous to the operations carried out by statistics: impersonal aggregates that highlight a collective situation. As a consequence, all of the main elements of an intervention scheme require statistics: data recording and collection, the inclusion of personal characteristics into comparative tables, the production of indicators demonstrating differentials and the assessment of their extent and variations, the development of quantified objectives for rectifying procedures and promoting equality, and the assessment of the effects of the programmes, etc."

It cannot be excuded that, despite the unambiguous terms of the Racial Equality and Employment Equality Directives - which both explicitly exclude to impose on the Member States an obligation to provide for the possibility to establish a presumption of discrimination by statistical means the European Court of Justice will be led to consider that such an obligation must be imposed as a condition for the effectiveness of the protection from discrimination. These directives, it will be recalled, are considered as merely implementing a more general principle, that of equal treatment. ${ }^{60}$ This not only justifies a broad reading of their requirements. It also may justify imposing on the Member States acting under European Community law - as they do when they implement the directives - obligations which go further than those explicit in the directives, where required by the principle of equal treatment. And, as recognized by the European Committee of Social Rights under the European Social Charter, allowing proof by statistics of instances of discrimination is required in order for the prohibition of indirect discrimination to be truly effective. ${ }^{61}$ Indeed, in the Enderby case, it is by

Netherlands (Medis Project (Measurement of Discriminations), co-ord. P. Simon (INED - Economie \& Humanisme), August 2004, p.82.

60 See the judgment of 22 November 2005 delivered in Case C-144/04, Mangold v Helm, nyr.

61 See European Committee of Social Rights, European Roma Rights Centre (ERRC) v Greece, collective complaint No. 15/2003, decision on the merits of 8 December 2004, at paras.21-28. The Committee notes in particular that, "in connection with its wish to assess the allegation of the discrimination against Roma made by the complainant organisation, the Government stated until recently that it was unable to provide any estimate whatsoever of the size of the groups concerned. To justify its position, it refers to legal and more specifically constitutional obstacles. The Committee considers that when the collection and storage of personal data is prevented for such reasons, but it is also generally acknowledged that a particular group is or could be discriminated against, the authorities have the responsibility for finding alternative means of assessing the extent of the problem and progress 
taking into account the fact that the plaintiff had submitted statistical evidence making it possible to establish a prima facie case of discrimination that the Court considered, "Where there is a prima facie case of discrimination, it is for the employer to show that there are objective reasons for the difference in pay. Workers would be unable to enforce the principle of equal pay before national courts if evidence of a prima facie case of discrimination did not shift to the employer the onus of showing that the pay differential is not in fact discriminatory". ${ }^{62}$ The Court has not feared in the past to restrict the procedural autonomy of the Member States, where it considered that the national rules relating to the presentation of evidence before the national jurisdictions were not sufficiently protective of the rights attributed by Community law. ${ }^{63}$ Now may be the time to develop this jurisprudence once step further.

\section{The Models of Equality and Personal Data Protection ${ }^{64}$}

The rules relating to the protection of personal data are sometimes seen to create specific obstacles both to the use by a potential victim of discrimination of statistics in order to shift the burden of proof on the respondent - in the Member States which have provided for this possibility in their implementation of the Racial Equality and Employment Equality Directives - and to the adoption of policies in favour of diversity by certain actors, in particular employers. A report presented in October 2003 to the European Commission (Directorate-General for Employment, Industrial Relations and Social Affairs) on the business case for diversity policies within the undertaking ${ }^{65}$ notes that one specific obstacle to the adoption and implementation of workforce diversity policies are the restrictions on the processing of sensitive data in the EU, which may make it impossible to

towards resolving it that are not subject to such constitutional restrictions" (at para.27). For the reaction of the Committee of Ministers of the Council of Europe, see Resolution Res ChS (2005)11, Collective complaint No. 15/2003 by the European Roma Rights Centre (ERRC) against Greece, adopted by the Committee of Ministers on 8 June 2005 at the 929th meeting of the Ministers' Deputies.

62 Case C-127/92, Enderby, [1993] ECR I-5535, para.18 (judgment of 27 October 1993).

63 See, e.g. Case 199/82, Administrazione delle Finanze delle Stato v Societa San Giorgio [1983] ECR 3595 (judgment of 9 November 1983); Case 22/84, Johnston $\mathrm{v}$ Chief Constable of the Royal Ulster Constabulary [1986] ECR 1651, para.20 (judgment of 15 May 1986).

64 See further on the questions discussed in this section two publications of the EU Network of Independent Experts on Fundamental Rights: Report on the situation of Fundamental Rights in the Union in 2003 (January 2004), at 97-100; and Thematic Comment No.3: The Protection of Minorities in the Union (March 2005), section 2 ("Monitoring the situation of minorities"). The documents of the Network may be consulted on: http://www.europa.eu.int/comm/justice _home/cfr_cdf/index_en.htm.

65 The Costs and Benefits of Diversity. A Study on Methods and Indicators to Measure the Cost-Effectiveness of Diversity Policies in Enterprises, report drawn up by the Centre for Strategy and Evaluation Service (CSES) on behalf of the European Commission. The report is based on a survey of 200 companies in $4 \mathrm{EU}$ countries, on literature reviews, on 8 case studies in 6 Member States, and on a number of interviews with a range of actors. See http://europa.eu.int/comm/ employment_social/fundamental_rights/prog/studies_en.htm. 
measure the evolution of the workforce, according to sexual orientation, race or ethnic origin, or religion. Without returning to that difficulty, a more recent report identifies "workforce profiling" as a good practice of companies in monitoring progress towards diversity. ${ }^{66}$ A study ${ }^{67}$ commissioned under the Community action programme to combat discrimination (2001-2006) concluded from a comparative study on the EU15 Member States, similarly, that data collection ought to be improved in order to gain a better understanding of discrimination in the EU Member States: "Data is needed to guide decision-makers, to facilitate awarenessraising activities, to enable the work of international human rights monitoring bodies, to facilitate legal action and to facilitate research on discrimination. Indeed, more than $90 \%$ of the experts surveyed were convinced that data collection on discrimination helps to improve the situation of individuals and groups vulnerable to discrimination." Among its recommendations, the report proposed that "States should develop their social and economic statistics in such a manner that they would be more useful in disclosing data on the (potentially) disadvantaged economic and social position of members of groups vulnerable to discrimination. Data related to employment, housing, education and income should be broken down by the grounds of discrimination, e.g. national origin, disability, gender and age", and that "Larger companies, public and private, should keep track of their workforce so as to be able to assess their recruitment, promotion and firing policies and practices". However, the survey prepared for that study also illustrated the high level of uncertainty about whether or not the existing rules on data protection represented an obstacle to the collection of data relating to discrimination, for the purposes recalled above. ${ }^{68}$

The authors of the 2004 Comparative Study on the collection of data to measure the extent and impact of discrimination within the United States, Canada, Australia, Great-Britain and the Netherlands noted the paradox underlying the debate in Europe on the implementation of anti-discrimination strategies:

"Although there is a lack of statistical indicators to assess the extent of discrimination in the Member States, the belief is widely shared that discrimination is widespread and that there is a need to mobilise all social institutions and stakeholders to reduce this discrimination. Nevertheless, the collection of statistics relating to ethnic or racial origin, religion, disability

66 This is defined thus: "Workforce profiling including ethnicity, nationalities, religions, languages spoken, gender and age mix to enable identification of particular areas of under-representation, as well as to enable comparisons against local area demographics: The Business Case for Diversity. Good Practices in the Workplace, September 2005, European Commission, Directorate-General for Employment, Social Affairs and Equal Opportunities (Unit D3), at 26.

67 Reuter et al., Study on data collection to measure the extent and impact of discrimination in Europe, Final report of 7 December 2004.

$6831 \%$ of the respondents to the survey were of the view that the data protection legislation does limit data collection. 36\% disagreed. 33\% did not know. There were no major differences in views provided by NGOs and Government representatives to this issue. See the report by Reuter et al., supra n.67, pp.158160. 
or sexual orientation has been the subject of strong resistance. The experience of the countries under study in this report demonstrates that the lack of sufficient statistics to illustrate and evaluate discrimination is not compatible with establishing an operational scheme whose main characteristic is the intensive use of statistical data. It appears necessary - and possible - to transcend the European paradox opposing the fight against discrimination and the production of 'sensitive' statistics." 69

It is therefore particularly important to clearly identify the limits imposed by data protection legislation on the use of statistical tools in order to monitor discrimination both in public policies and in private settings, including in particular within the workforce of private undertakings. This is required both for reasons of legal certainty, as the reluctance of both public and private actors to perform such monitoring may be attributed, in a number of cases, to misconceptions about the requirements of the rules relating to data protection, and in order to identify whether there may be a need to arbitrate a conflict between those requirements and effective anti-discrimination strategies. It is the purpose of this section to identify whether such conflict indeed exists, and if so, what may be done to alleviate it.

The general framework is as follows. The processing of personal data within the EU Member States must comply with the guarantees stipulated by Article 8 of the European Convention on Human Rights ${ }^{70}$ and by the Council of Europe Convention (No. 108) for the Protection of Individuals with regard to Automatic Processing of Personal Data. ${ }^{71}$ Under this latter instrument, personal data undergoing automatic processing shall be "obtained and processed fairly and lawfully", "stored for specified and legitimate purposes" and processed by means "adequate, relevant and not excessive in relation to the purposes for which they are stored". ${ }^{72}$ According to Convention No. 108 of the Council of Europe, personal data cannot be used in a way incompatible with the purposes for which they are collected. ${ }^{73}$ States have to take the appropriate security measures for the protection of personal data stored in automated data files against unauthorised access, alteration or

69 Supra, n.59, at 87.

70 The European Court of Human Rights has interpreted this provision as protecting the individual from the processing of data, whether relating to his or her private or public activities, which may be traced back to an identified or identifiable individual (Eur Ct HR (GC), Rotaru v Romania (Appl. No. 28341/95) judgment of 4 May 2000 , at $\S 43$ (noting in particular that "public information can fall within the scope of private life where it is systematically collected and stored in files held by the authorities")). However, the Court has rejected an extensive understanding of this case-law which would have created an obstacle to the use of any information, even recent, concerning a specified individual, in order to adopt certain decisions affecting that individual: see the partial inadmissibility decision of 6 March 2003 in Zdanoka c. Lettonie (Appl. No. 58278/00).

71 This Convention has been opened for signature on 28 January 1981.

72 Art.5 (a), (b) and (c).

73 Art.5(b). 
dissemination. ${ }^{74}$ Under this same Convention, data relating to ethnic origin or the religion of an individual may not be automatically processed, unless domestic law provides for appropriate safeguards. ${ }^{75}$ Within the European Union, Directive 95/46/CE of the European Parliament and the Council of 24 October 1995 on the protection of individuals with regard to the processing of personal data and on the free movement of such data (hereafter referred to as the "Personal Data Directive") ${ }^{76}$ extends the protection offered by the 1981 Convention No. 108, in particular insofar as it applies also to the processing of personal data by non automatic means. Moreover, Article 3 (1) of the Council of Europe Framework Convention on National Minorities provides that every person shall have the right freely to choose to be treated or not to be treated as belonging to a national minority and that no disadvantage shall result from this choice. ${ }^{77}$ Under this provision, State authorities thus cannot impose the quality of belonging to a minority on individuals. ${ }^{78}$ Finally, the principles of Recommendation No. 97(18) of the Committee of Ministers of the Council of Europe concerning the protection of personal data collected and processed for statistical purposes ${ }^{79}$ and Recommendation No. (91) 10 of the Committee of Ministers on the communication to third parties of personal data held by public bodies must be taken into account.

This section explains why, contrary perhaps to a relatively widespread perception, the rules relating to the processing of personal data, including the heightened protection of sensitive data relating to the ethnic origin, the religious beliefs or the state of health (and the disability) of the individual, should not be seen as an obstacle to an adequate monitoring of the impact on certain groups protected from discrimination of public policies, legislation or private practices. On the contrary, they constitute a necessary and welcome safeguard against any risk of abuse in the process of such monitoring, a precondition for which therefore is that these rules protecting personal data are strictly adhered to. Although a number of States seem to consider that this form of monitoring is in conflict with the protection of personal data, especially as guaranteed under their national legislation implementing Directive 95/46/EC on the protection of individuals with regard to the

${ }^{74}$ See art.7. Appropriate security measures shall be taken as well for the protection of these personal data against accidental or unauthorised destruction or accidental loss.

75 Art.6. The Advisory Committee of the Framework Convention also emphasized the need to protect the confidentiality of the data relating to the membership of national (ethnic, religious, linguistic or cultural) minorities (Opinion on Italy, 14 September 2001, ACFC/OP/I(2002)007, para.20).

76 OJ L 28 of 23.11.1995, p.31.

77 Therefore, an obligation to reply to a question relating to the affiliation with a minority would not be compatible with art.3(1) of the Framework Convention on National Minorities: see Opinion of the Advisory Committee of the Framework Convention on Estonia, 14 September 2001, ACFC/INF/OP/I(2002)005, para.19; Opinion on Poland, 27 November 2003, ACFC/INF/OP/I(2004)005, para.24.

78 This right implies as well that each person shall have the liberty to request to stop being treated as belonging to a minority (see Opinion on Cyprus, 6 April 2001, ACFC/OP/I(2002)004, para.18).

79 Adopted by the Committee of Ministers on 30 September 1997 at the 602nd meeting of the Ministers' Deputies. 
processing of personal data and on the free movement of such data, there is no such contradiction in fact. To understand why, it is useful to distinguish general monitoring through statistical means, from affirmative policies implying the processing of personal data.

\title{
3.1. Monitoring the potentially discriminatory impact through statistical means
}

According to Article 2(a) of the Personal Data Directive, personal data are:

\begin{abstract}
"any information relating to an identified or identifiable natural person ('data subject'); an identifiable person is one who can be identified, directly or indirectly, in particular by reference to an identification number or to one or more factors specific to his physical, physiological, mental, economic, cultural or social identity."
\end{abstract}

Therefore, once personal data are made anonymous in order to be used in statistics, the information contained in such statistics should not be considered as personal data. This should be taken into consideration when comparing the different forms under which the impact on certain specified categories of persons of certain policies, legislations or practices may be monitored. Such a monitoring may consist in collecting information from the individuals concerned, in order to use this information for statistical purposes after these data are anonymized. It may also be based on the processing of information not obtained directly from the individuals concerned for that purpose but processed and communicated for statistical purposes, a process which is referred to as "secondary collection of personal data". Finally, it may be based on other reliable techniques, such as those traditionally used in social science empirical research, including the use of representative samples or personal interviews conducted by independent researchers, under the principle of anonymity. In fact, this latter technique may produce results more reliable than those obtained through the collection of data by the use of individual questionnaires initially linked to identified or identifiable individuals, because of the risks of underreporting or overreporting implied in the use of such questionnaires to be completed by the individuals concerned.

Recital 29 of the Preamble and Article 6(1)(b) of the Personal Data Directive make it clear that, insofar as the initial collection of personal data took place for specified, explicit and legitimate purposes, the further processing of personal data for historical, statistical or scientific purposes should not generally be considered incompatible with the purposes for which the data have previously been collected provided that Member States furnish suitable safeguards, which must in particular rule out the use of the data in support of measures or decisions regarding any particular individual. Insofar as sensitive data are concerned, relating in particular to the race or ethnic origin, the religion or the disability of the data subject, the Directive authorizes the Member States, when justified by grounds of important public interest, to derogate from the prohibition on processing sensitive categories of data where important reasons of public interest so justify, for instance for the 
preparation of government statistics. ${ }^{80}$ However, where the monitoring involves the use of personal data, the principles enumerated in the Recommendation No. R (97) 18 of the Committee of Ministers of the Council of Europe to the Member States concerning the protection of personal data collected and processed for statistical purposes, ${ }^{81}$ should be complied with. In particular, this Recommendation prescribes that personal data collected and processed for statistical purposes shall be made anonymous as soon as they are no longer necessary in an identifiable form (Principle 3.3), i.e. immediately after the end of the data collection or of any checking or matching operations which follow the collection, except if identification data remain necessary for statistical purposes and the identification data are separated and conserved separately from other personal data, unless it is manifestly unreasonable or impracticable to do so (Principle 8.1 and Principle 10.1), or if the very nature of statistical processing necessitates the starting of other processing operations before the data have been made anonymous and as long as all the appropriate technical and organisational measures have been taken to ensure the confidentiality of personal data, including measures against unauthorised access, alteration, communication or any other form of unauthorised processing (Principle 8.1. and Principle 15). It also prescribes that, where personal data are collected and processed for statistical purposes, they shall serve only those purposes, and shall therefore not be used to take a decision or measure in respect of the data subject, nor to supplement or correct files containing personal data which are processed for non-statistical purposes (paragraph 4.1); and that, in order for the processing of personal data for statistical purposes to remain proportionate, only those personal data shall be collected and processed which are necessary for the statistical purposes to be achieved, which implies in particular that identification data shall only be collected and processed if this is necessary (paragraph 4.7). Specific principles governing the information of the persons concerned apply, moreover, in the context of either the primary or the secondary collection of personal data for statistical purposes (Principles 5.1 to 5.5).

Recommendation No. R (97) 18 provides that when, for statistical purposes linked to monitoring, personal data are collected from the person concerned, he/she must be informed of the compulsory or optional nature of the response and the legal basis, if any, of the collection (Principle 5.1), and any penalties for a refusal to reply may only be imposed by law (Principle 6.4). However, where the data collected from the person concerned relate directly or indirectly to the membership of the person of a minority, replying to such a question should always be optional. This follows both from Article 3 of the Framework Convention on the Protection of National Minorities, referred to above, which provides that every person belonging to a national minority shall have the right freely to choose to be treated as such. Moreover, Principle 6.2 of Recommendation No. R (97) 18 provides that:

"Where the consent of the data subject is required for the collection or processing of sensitive data, it shall be explicit, free and informed. The legitimate objective of the survey may

80 Recital 34 of the Preamble and art.8(4) of the Personal Data Directive.

${ }^{81}$ Cited supra, n.79. 
not be considered to outweigh the requirement of obtaining such consent unless an important public interest justifies the exception.

Where the monitoring involves the use of data which have not been collected directly from the individual whom these data relate to (secondary collection of personal data), this individual should in principle be informed of the use of these data when the data are recorded or at the latest when the data are first disclosed to a third party, for instance where an employer communicates certain statistical data on the ethnic break-up of his workforce to the public authorities, unless providing the individuals concerned with such information would involve disproportionate efforts, for instance because of the large number of persons concerned or because the further processing is purely for statistical purposes." ${ }^{2}$

The importance of these safeguards could hardly be overstated. They should prevent the misuse of personal data in the context of their processing, after anonymization, for statistical purposes in order to monitor the potentially discriminatory impact of legislations, policies or practices. None of these safeguards, however, impose insuperable obstacles to such processing. There is no conflict between personal data protection and the monitoring of discrimination through statistical means, insofar as the objective of such monitoring is to gain a better understanding of the over- or underrepresentation of certain groups in particular sectors or at certain levels, and to measure progress, in order to identify the need to act and to select the most effective course of action.

In principle, neither should there be such a conflict where the preparation of such statistics is required in order to make it possible for individuals claiming that they are victims of discrimination to bring forward certain statistical data which, if these data make a sufficiently convincing case that such discrimination has indeed occurred, will shift the burden of proof on the respondent. This calls for an important proviso, however. In the Member States which allow the victim of discrimination to bring forward statistics in order to establish a presumption of discrimination, the employer may have to shield him- or herself against legal action for alleged discrimination on the basis of certain statistical data on the composition of the workforce or the disproportionate impact of any system that he has put in place. This may require the continuous monitoring of the consequences of the decisions adopted by the employer in terms of their repercussions on the different categories of workers or prospective workers. Indeed, both experience in countries where the concept of disparate impact discrimination is used and academic commentary ${ }^{83}$ show that allowing for the use of statistics by

82 This follows from Recitals 39 and 40 of the Preamble of the Personal Data Directive, and from its Article 11. This is also compatible with Principles 5.2. and 5.3. of Recommendation No. R (97) 18 of the Committee of Ministers of the Council of Europe to the Member States concerning the protection of personal data collected and processed for statistical purposes.

83 See Goodman, "Affirmative Action", Phil. \& Public Affairs, vol. 5, No. 2, Winter 1976, reprinted in M. Cohen, Th. Nagel and Th. Scanlon (eds.), Equality and Preferential Treatment (Princeton, Princeton Univ. Press, 1977) 192 at 198; 
alleged victims of discrimination leads naturally to the potential respondents in disparate impact discrimination cases "operating by the numbers" in order to avoid liability for this specific form of discrimination: where it is not possible to justify the necessity of the full set of criteria, both formal and informal, which are relied upon in order to make a selection, the actor generally will have no other choice but to ensure, "artificially" as it were, that those selection processes lead to an adequate (roughly proportionate) representation of all categories protected under an anti-discrimination legislation.

This would not appear to be conflicting with personal data protection legislation, however. Under the 1995 Personal Data Directive, the processing of sensitive data by an employer may be allowed for the purpose of complying with the obligations imposed on him by labour law, insofar as such law provides adequate safeguards. ${ }^{84}$ Thus, in the Member States which allow the victim of discrimination to bring forward statistics in order to establish a presumption of discrimination, and where the employer therefore may have to monitor the impact of his decisions on the workforce, the employer may be justified in processing "sensitive" data such as membership of a racial or ethnic group, religion, or health (disability) for that purpose. Outside the field of employment (particularly in education, social protection, social advantages and the supply of goods and services, to which the Racial Equality Directive applies), the Personal Data Directive also allows the processing of sensitive data where it is "necessary for the establishment, exercise or defence of legal claims". ${ }^{85}$

In examining the question of affirmative action taken by certain actors in order to protect themselves from potential legal liability for disparate impact discrimination, we have already anticipated on the developments of the next paragraph. It is to this question that we now turn.

\subsection{Granting special rights in the context of affirmative action policies}

In certain cases, the processing of personal data, relating for instance to the ethnic or religious affiliation of an individual or to his or her disability, will be required not only for statistical purposes, in order to ensure that the situation of minorities under generally applicable laws or policies is adequately monitored, but also in order to grant to the individual members of minorities certain advantages or to offer them specific treatment. This, indeed, will be required under affirmative action programmes, which constitute a sub-part of positive action programmes in general. ${ }^{86}$ The

Meyer, "Finding a 'Manifest Imbalance': The Case for a Unified Statistical Test for Voluntary Affirmative Action Under Title VII", 87 Mich. L. Rev 1986 (1989).

84 Art.8, s.2, b), of Directive 95/46/EC, quoted infra in s.2.2, stipulates that national law should offer specific safeguards, in other words, that it should strictly regulate the method used by an employer and the use made of those data, in particular the way in which those data are collected (only self-identification of the worker with certain categories makes this classification acceptable), the protection of the data (persons having access to those data and conditions of access), and the exercise by the person concerned of rights of access and rectification.

85 See art.8, s. 2, e) of Directive 95/46/EC, quoted infra in s.2.2.

${ }^{86}$ See infra, s.4. 
relevant rules relating to the protection of personal data must be fully complied with in the framework of such a policy. In particular, the processing of "sensitive" data on racial origin, religious or other beliefs, health (disability) or sex life is subject to particularly strict conditions, in order to reflect the risk of discrimination involved in the use of such data.

The Personal Data Directive provides that the EU Member States shall in principle prohibit the processing of sensitive data. These are defined as "personal data revealing racial or ethnic origin, political opinions, religious or philosophical beliefs, trade-union membership, and the processing of data concerning health or sex life" (Article 8 paragraph 1). ${ }^{87}$ Directive 95/46/EC only allows the processing of sensitive data in five situations, among which two are relevant in this context:

"(a) the data subject has given his explicit consent to the processing of those data, except where the laws of the Member State provide that the prohibition [imposed on the processing of sensitive data] may not be lifted by the data subject's giving his consent; or (...)

(e) the processing relates to data which are manifestly made public by the data subject or is necessary for the establishment, exercise or defence of legal claims."

Insofar as, per definition, the processing of sensitive personal data in order to grant a preferential treatment will be advantageous to the data subject, it will typically be possible to obtain the consent of that person to the processing of such data. In fact, at least with respect to the members of ethnic or religious minorities whose membership in those groups is defined by their ethnic origin or their religion, which are two "sensitive" traits, there exists a complementarity between that derogation to the principle according to which sensitive data may not be processed on the one hand, and the rule stipulated in Article 3(1) of the Framework Convention on the Protection of National Minorities which, as the reader may recall, provides that every person shall have the right freely to choose to be treated or not to be treated as belonging to a national minority and that no disadvantage shall result from this choice. As a result of these rules, where a potential beneficiary of an affirmative action programme agrees to identify him- or herself as having a particular ethnicity or religious faith, that individual will be granted the preferential treatment afforded under the programme; if the potential beneficiary refuses to thus identify to one ethnic or religious group, he or she will simply be considered to be exercising the right not to be treated as belonging to an ethnic or religious minority.

This raises, of course, the question of the validity of the consent. In the context of the 1995 Personal Data Directive, the notion of "consent" is defined as the "freely given specific and informed indication of his wishes by which the data subject signifies his agreement to personal data relating to

${ }^{87}$ See also art.6 of the Council of Europe Convention for the Protection of Individuals with regard to Automatic Processing of Personal Data, referred to supra, n.71 (which says that sensitive data "may not be processed automatically unless domestic law provides appropriate safeguards"). 
him being processed". 88 Two questions arise, however, even where the consent is free, informed, and specific, as required by this definition. First, Article 3(1) of the Framework Convention on the Protection of National Minorities states that no disadvantage shall result from the choice of the individual not to be treated as a member of a minority. Would not benefiting from an affirmative action policy not constitute precisely such a disadvantage? Second, in the specific context of the employment relationship, reliance on the consent of the worker either in order to legitimate the processing of personal data generally ${ }^{89}$ or in the context of the derogation to the processing of sensitive personal data, is generally considered highly suspicious, because of the power imbalance between the processor (the employer) and the data subject (the worker). Indeed, this was one of the important questions raised in the course of the consultations with the social partners which the European Commission conducted, in accordance with Article 138(2) EC, about a possible directive specifically addressed at the protection of personal data in employment.

These arguments against the reliance on the consent of the data subject who may benefit from an affirmative action policy do not seem to be decisive, however. The alternatives to this solution would consist either in not requesting consent from the individual concerned for the processing of personal data in the context of an affirmative action programme, or in renouncing the idea of such a programme altogether. But these alternatives are both unsatisfactory, and neither appears more favourable to the potential beneficiary of affirmative action. Indeed, the first solution (to dispense with the consent of the data subject) would be in clear violation of Article 3(1) of the Framework Convention for the Protection of National Minorities, where ethnic or religious minorities are concerned, as well as with the interpretation given by the Committee on the Elimination of Racial Discrimination to Article 1(4) of the International Convention on the Elimination of All Forms of Racial Discrimination; ${ }^{90}$ and the second solution would run counter to the consistent view of the Advisory Committee of the Framework Convention that affirmative action programmes seeking to contribute to the effective integration of minorities are in principle desirable. ${ }^{91}$ As to the fragility of consent in the context of the employment relationship, it is a concern which has been expressed - most notably, by the Working Party created under Article 29 of the Personal Data Directive ${ }^{92}$ - in the specific situation of the recruitment process, where, as a matter of course, a refusal by the candidate to a job to provide the employer with the information requested may lead the

88 Art.2, h, of the Personal Data Directive.

89 Art.7, a, of the Personal Data Directive provides that if it is unambiguous, the consent of the data subject to the processing of personal data may legitimate this processing.

90 The Committee on the Elimination of Racial Discrimination adopted General Recommendation VIII at its thirty-eighth session in 1990, in which it concluded that the identification of individuals as being members of a particular racial or ethnic group or groups "shall, if no justification exists to the contrary, be based upon self-identification by the individual concerned" (UN doc. A/45/18).

91 See infra, s.4.3.b, and text corresponding to n.133.

92 Opinion No. 8/2001 on the processing of personal data in the employment context, WP 48, 5062/01, 13 September 2001. 
employer to deny the position to the individual concerned. ${ }^{93}$ However, where the consent of the worker is requested in order to implement an affirmative action programme, it may not be presumed that it is coerced or particularly suspect: ${ }^{94}$ typically, the employer will seek this information from the employee in order to comply with the legal obligations imposed on the employer, and it will be in the interest of both that the employee identifies him- or herself with a particular group benefiting from the policy. ${ }^{95}$

\subsection{Conclusion}

It has been the argument of this section of the article that under European Community law, personal data protection does not constitute an obstacle to moving towards a more affirmative model of equality, or one which, at a minimum, allows victims to establish a presumption of discrimination by bringing forward statistical data, thus allowing for the concept of disparate impact discrimination to emerge beyond the context of equal treatment between men and women. A distinct question is whether the requirements of the Personal Data Directive should not be clarified in this respect. In its Thematic Comment No. 3 concerning the rights of minorities in the Union, the EU Network of Independent Experts on Fundamental Rights suggested that an opinion by the Working Party established under Article 29 of the Personal Data Directive would be welcome, in order to clarify the requirements of the directive and to avoid any misrepresentations which would discourage the Member States from moving towards more effective models of equality, or from invoking personal data protection legislation as a pretext for not improving the monitoring of the situation of certain groups under their jurisdiction. ${ }^{96}$ The different national sensitivities which exist in this area are of course to be fully respected. At the same time however, diverging interpretations of the Personal Data Directive should be avoided, not only for obvious reasons of legal certainty, but also because any differences in approach between Member States on this issue may pose a threat to the prime objective of the Directive when it was adopted, which was

93 See p.32 of Opinion No. 8/2001, supra n.92.

94 It may be significant in this regard that, while it expresses its doubts about the validity of the consent given by the employee to the processing of personal data, considering the fundamental inequality between the parties to the employment contract, the European Commission notes, in its preparatory document to the Second consultation phase with the social partners on the protection of personal data of workers, that personal data concerning racial and ethnic origin or religious convictions may be processed in accordance with the law, in circumstances where the law allows for a differential treatment on any of these grounds, in particular where genuine occupational requirements or positive action measures are concerned (at p.14).

95 For a more elaborate discussion of this question, see O. De Schutter, "La protection du travailleur vis-à-vis des nouvelles technologies dans l'emploi", Revue trimestrielle des droits de l'homme, 2003, No. 54, pp.627-664.

96 EU Network of Independent Experts on Fundamental Rights, Thematic Comment No.3: The Rights of Minorities in the European Union, March 2005, at p.18, available at http://www.europa.eu.int/comm/justice_home/cfr_cdf/index_en.htm. 
to guarantee the free movement of data between Member States, particularly in order to facilitate cross-border economic activity. ${ }^{97}$

\section{The affirmative dimension of the principle of equal treatment: positive action}

\subsection{The many faces of positive action}

Positive action comes in many forms. From the legal point of view, a fundamental distinction should be made between forms of positive action which do not create a risk of discrimination against the members of the group which the action does not benefit, and the forms which do entail such a risk (referred to here as "affirmative action"). Where, for example, an employer publicizes job advertisements in a paper read primarily by the members of a specific ethnic community, or includes on the job advertisement that minorities or women are encouraged to apply, or indicates that the undertaking has a nursery in order to attract applications from women, such measures - although they do demonstrate a willingness to go beyond a nondiscrimination policy in order to achieve a better balance within the workforce - are not forms of "preferential treatment" which may be construed as a derogation from the requirement of formal equality. ${ }^{98}$ On the other hand, the practice of "quotas" or set-asides, whether rigid (the reservation of a specified percentage of places to the members of underrepresented groups) or flexible (preferential treatment of a candidate belonging to the under-represented category where the competing candidates are equally qualified), or conceived as part of diversity plans setting certain targets to be achieved and providing for the monitoring of the progress made

97 See Communication of the Commission on the implementation of Directive 95/46/CE, COM(2003) 265 final, 15.5.2003. The Commission recalls its view in the evaluation of the Personal Data Directive that Internal Market legislation should "provide a level playing field for economic operators in different Member States; help to simplify the regulatory environment in the interests of both good governance and competitiveness; and tend to encourage rather than hinder crossborder activity within the EU". The realization of this objective would be threatened, in particular, if differences in approach between national laws have the effect of impeding the implementation of a staff policy encouraging diversity in companies that operate in several States.

98 They correspond to what, in a Report prepared within the Sub-Commission for the Promotion and Protection of Human Rights, M. Bossuyt describes as "affirmative mobilization" ("when, through affirmative recruitment, the targeted groups are aggressively encouraged and sensitized to apply for a social good, such as a job or a place in an educational institution ") or "affirmative fairness" ("when a meticulous examination takes place in order to make sure that members of target groups have been treated fairly in the attribution of social goods, such as entering an educational institution, receiving a job or promotion"). Such measures, while "dedicated to overcoming the social problems of a target group, (...) do not themselves entail discrimination against people who are not members of that group. Rather, they place the costs of affirmative action on the whole society" ("The concept and practice of affirmative action", Final report submitted by Mr. Marc Bossuyt, Special Rapporteur, in accordance with resolution 1998/5 of the Sub-Commission for the Promotion and Protection of Human Rights, UN doc. E/CN.4/Sub.2/2002/21, 17 June 2002, para.72-74). 
in this direction, ${ }^{99}$ may be seen as constituting such a derogation. This will be the case at least where the principle of equal treatment is formulated symmetrically - on the basis of a defined characteristic, such as race or ethnic origin, or sex, rather than in favour of one specified category, such as ethnic minorities or women - so that the specific advantages recognized to the members of one group defined according to this characteristic will be seen by the members of the other group as disadvantaging them.

Insofar as an affirmative action policy is scrutinized for its compatibility vel non with the requirements of the principle of equal treatment, two questions will matter. First, it will be necessary to inquire into the aims pursued by such a policy, in order to decide whether these aims are legitimate and may justify the restriction to the right of each individual to be treated "equally", i.e. on the basis of his or her individual situation, rather than as a member of the group to which he or she belongs. Three distinct rationales may be invoked in this regard. ${ }^{100}$ A first rationale is backward-looking. Affirmative action is presented, here, as compensatory: because the group to which A belongs has, in the past, been excluded or denied certain benefits, in comparison to the group to which B belongs, it will be justified to grant a preferential treatment to $\mathrm{A}$, in order to overcome the legacy of this past discrimination. A second rationale focuses not on the past, but on the present. It sees affirmative action as a tool necessary to establish "equality in fact", rather than mere "formal equality", because the latter (equality before the law, i.e., non-discrimination) would remain blind to certain realities conscious or unconscious prejudice or stereotypes - which, unless taken into account, will work to the disadvantage of the members of a defined category. The trait of the individual, which characterizes that individual as the member of a group, is thus taken as a proxy for a disadvantage which it is the objective of the affirmative action policy to remedy. A third rationale may be said to be "forward-looking". It sees affirmative action as a tool to promote diversity or proportionate representation, in sectors or at levels where it matters that all the sub-groups of the community are fairly represented.

Once that rationale justifying affirmative action as a restriction to the principle of (formal) equal treatment is identified, the second question will be which level of scrutiny should be applied. Whether affirmative action policies are subjected to a strict scrutiny, requiring that they be demonstrated to be both appropriate and strictly proportionate, i.e. necessary, for the achievement of the aims pursued, or to a looser form of scrutiny, will depend largely on the understanding of affirmative action either as a means to achieve equal treatment (complementing the requirement of formal equality as non-discrimination) or as a mere derogation to that principle. It may also depend on the more or less suspect character of the trait on which the affirmative action policy - for instance, race or ethnic origin will usually be considered highly suspect, while sex may be considered less suspect.

99 For a discussion built around such a typology, see D. Schiek, "Sex Equality Law After Kalanke and Marschall", 4 Eur. L. Journal 148 (1998).

100 For a more systematic approach, see C. McCrudden, "Rethinking positive action", Industrial Law Journal, 1986, vol.15, pp.219-243; or "The concept and practice of affirmative action", supra n.98. 


\subsection{The case-law of the European Court of Justice}

The case-law of the European Court of Justice on the question of affirmative action in the only context where it has arisen to date before the court - where such affirmative action was instituted in favour of women ${ }^{101}$ and was denounced as discriminatory towards men - is not fully consistent. It nevertheless may be examined on the basis of the typology above. In order to understand the position of the Court, the legal framework in which it operates should first be recalled. When it was initially adopted, Council Directive 76/207/EEC of 9 February 1976 on the implementation of the principle of equal treatment for men and women as regards access to employment, vocational training and promotion, and working conditions, ${ }^{102}$ after defining the principle of equal treatment as the absence of any discrimination on grounds of sex, whether direct or indirect, provided in Article 2(4) that the Directive "shall be without prejudice to measures to promote equal opportunity for men and women, in particular by removing existing inequalities which affect women's opportunities". These formulations refer symmetrically to both women and men, thus protecting the members of both groups from sex-based discrimination, while seeming to exempt affirmative action measures benefiting either men or women. Moreover, on 13 December 1984, the Council adopted Recommendation 84/635/EEC on the promotion of positive action for women, which emphasized that "existing legal provisions on equal treatment, which are designed to afford rights to individuals, are inadequate for the elimination of all existing inequalities unless parallel action is taken by governments, both sides of industry and other bodies concerned, to counteract the prejudicial effects on women in employment which arise from social attitudes, behaviour and structures". ${ }^{103}$ The Recommendation thus encouraged the Member States:

"to adopt a positive action policy designed to eliminate existing inequalities affecting women in working life and to promote a better balance between the sexes in employment, comprising appropriate general and specific measures, (...) in order: (a) to eliminate or counteract the prejudicial effects on women in employment or seeking employment which arise from existing attitudes, behaviour and structures based on the idea of a traditional division of roles in society between men and women; (b) to encourage the participation of women in various occupations in those sectors of working life where they are at present under-represented, particularly in the sectors of the future, and at higher levels of responsibility in order to achieve better use of all human resources."

When it was confronted to affirmative action policies adopted by the Member States, the European Court of Justice nevertheless considered that "as a derogation from an individual right laid down in the Directive, Article 2(4) must be interpreted strictly". ${ }^{104}$ In Kalanke, its first judgment on this

101 See however infra, n.117 and the corresponding text.

102 OJ 1976 L 39, p.40.

103 OJ 1984 L 331, p.34.

104 Case C-450/93, Kalanke v Freie Hansestadt Bremen [1995] ECR I-3051. 
issue, which it delivered on 17 October 1995, the Court arrived at the conclusion that the provision of the 1990 Bremen Law on Equal Treatment for Men and Women in the Public Service which provided that women who have the same qualifications as men applying for the same post are to be given priority in sectors where they are under-represented, went beyond what was authorized by Article 2(4) of Directive 76/207/EEC. "National rules which guarantee women absolute and unconditional priority for appointment or promotion", said the Court, "go beyond promoting equal opportunities and overstep the limits of the exception in Article 2(4) of the Directive", and furthermore "in so far as it seeks to achieve equal representation of men and women in all grades and levels within a department, (...) [the Bremen Law] substitutes for equality of opportunity as envisaged in Article 2(4) the result which is only to be arrived at by providing such equality of opportunity". ${ }^{105}$

On 2 October 1997, the Heads of State and Governments of the European Union signed the Treaty of Amsterdam, which entered into force on May 1st, 1999. Article 119 EEC (now Article 141 EC) was substantially modified on that occasion. It now provided in paragraph 4 that:

"With a view to ensuring full equality in practice between men and women in working life, the principle of equal treatment shall not prevent any Member State from maintaining or adopting measures providing for specific advantages in order to make it easier for the underrepresented sex to pursue a vocational activity or to prevent or compensate for disadvantages in professional careers."106

Although the Treaty of Amsterdam was not in force yet when the Court decided its second affirmative action case, it may have influenced the outcome, because of the strong signal sent to the Court that the Member States intended to maintain and develop affirmative action and did not consider that this should be seen as conflicting with the requirements of equal treatment. In Marschall, which it decided on 11 November 1997, the Court distinguished Kalanke, on the basis that the challenged provision contained a "savings clause" (Öffnungsklausel), to the effect that women are not to be given priority in promotion if reasons specific to an individual male candidate tilt the balance in his favour. ${ }^{107}$ Indeed, the 1981 Law on Civil Servants of the Land of Nordrhein-Westfalen, as last amended in 1995, provided that "Where, in the sector of the authority responsible for promotion, there are fewer women than men in the particular higher grade post in the career bracket, women are to be given priority for promotion in the event of equal suitability, competence and professional performance, unless reasons specific to an individual [male] candidate tilt the balance in his favour". Although this element appears to be decisive in the reasoning of

105 Paras.23-24 of the judgment.

106 The language in art.141(4) EC is symmetrical, applying identically to both women and men. However, Declaration No. 28 on art.141(4) (formerly art.119(4)) of the Treaty establishing the European Community, annexed to the Treaty of Amsterdam, states: "When adopting measures referred to in art.141(4) of the Treaty establishing the European Community, Member States should, in the first instance, aim at improving the situation of women in working life".

107 Para.24. 
the Court, ${ }^{108}$ the judgment also illustrates the willingness of the Court to adopt a less formalistic stance towards the situation of women in the labor market and the virtues of equality of opportunities. It recognized that "even where male and female candidates are equally qualified, male candidates tend to be promoted in preference to female candidates particularly because of prejudices and stereotypes concerning the role and capacities of women in working life and the fear, for example, that women will interrupt their careers more frequently, that owing to household and family duties they will be less flexible in their working hours, or that they will be absent from work more frequently because of pregnancy, childbirth and breastfeeding. For these reasons, the mere fact that a male candidate and a female candidate are equally qualified does not mean that they have the same chances". ${ }^{109}$

The judgment in the case of Badeck and others, delivered by the Court of Justice on 28 March 2000, ${ }^{110}$ confirmed the lessons drawn from the combination of the Kalanke and Marschall judgments. Faced with a series of provisions of the law of the Land of Hesse relating to the equality of men and women and the elimination of discrimination against women in public service, the Court of Justice began by reiterating the validity of the criterion set in the Marschall judgment: priority given to women in promotion where they are underrepresented in public service is compatible with Article 2, paragraphs 1 and 4, of Directive 76/207/EEC, insofar as it does not automatically and unconditionally give priority to women when women and men are equally qualified, and the candidatures are the subject of an objective assessment which takes account of the specific personal situations of all candidates 111 on the basis of "secondary" non-discriminatory criteria. However, the Court added several specifications to this criterion, three of which are of particular relevance to our purpose. Firstly, even if, in principle, "automatic" - or "absolute and unconditional" - preferential treatment exceeds the limits of the exception to the individual right to equal treatment laid down in Article 2 (4) of Directive 76/207/EEC, such an automatism may be justified when such preference is based on a quantitative criterion constituted by an "actual fact", for example, "by reference to the number of persons who have received appropriate training". ${ }^{112}$ Secondly, when "places in training with a view to obtaining qualifications with the

108 While confirming that art.2(4) of the Directive is to be construed strictly as it constitutes a limited exception to the individual right to equal treatment laid down in art.2(1), the Court concludes that the rule at stake does not exceed the limits of the exception, insofar as "in each individual case, [the savings clause] provides for male candidates who are equally as qualified as the female candidates a guarantee that the candidatures will be the subject of an objective assessment which will take account of all criteria specific to the individual candidates and will override the priority accorded to female candidates where one or more of those criteria tilts the balance in favour of the male candidate. In this respect, however, it should be remembered that those criteria must not be such as to discriminate against female candidates" (para.33).

109 Case C-409/95, Marschall v Land Nordrhein-Westfalen [1997] ECR I-6363.

110 Case C-158/97, Badeck and others [2000] ECR I-1875.

111 These two criteria are, strictly speaking, neither alternative nor cumulative. As their origin in the rules at issue in the Marschall case shows, they are in fact two ways of formulating one and the same criterion.

112 Para.42. 
prospect of subsequent access to trained occupations in the public service"113 are at stake, rather than actual employment positions, the imposition of an absolute preference aimed at achieving a balanced representation may be admissible, insofar as (1) "despite appropriate measures for drawing the attention of women to the training places available"114 there may not be enough applications from women, and (2) since the State does not have a monopoly for training places where a balanced representation of men and women is sought, "no male candidate is definitively excluded from training", as places are also available in the private sector. ${ }^{115}$ Thirdly, insofar as it aims to promote "equal opportunity for men and women" without guaranteeing a result, a set of rules which ensures that women with the necessary qualifications will be called to interview for jobs in public service sectors where they are underrepresented does not constitute a prohibited discrimination, but instead should be considered a measure of affirmative action allowed by Article 2(4) of Directive 76/207/EEC. ${ }^{116}$

After Kalanke, Marschall, and Badeck, which set the stage for all the later case-law, the European Court of Justice delivered four more judgments, including two more answers to requests for preliminary rulings from German courts, on the admissibility of affirmative action policies in favour of women or, in one case, ${ }^{117}$ men. The EFTA Court also delivered one judgment on this issue. This is not the place to review this case-law in detail. The following table summarizes the issues the European Courts were presented with in these cases as well as the answers they provided:

113 Para.52.

114 Paras.51 and 55.

115 Para.53.

116 Para.56 to 63.

117 See Case C-79/99, Schnorbus [2000] ECR I-10997. The case is also atypical in another respect, and some would contest its classification among "affirmative action" cases. The Court decided in this case that a measure giving priority to persons who have completed compulsory military or civilian service, although constituting an instance of indirect discrimination in favour of men (who alone are subject by law to such an obligation), cannot be regarded as contrary to the principle of equal treatment for men and women, as "the provision at issue, which takes account of the delay experienced in the progress of their education by applicants who have been required to do military or civilian service, is objective in nature and prompted solely by the desire to counterbalance to some extent the effects of that delay" (para.44), and as moreover "the advantage conferred on the persons concerned, whose enjoyment of priority may operate to the detriment of other applicants only for a maximum of 12 months, does not seem disproportionate, since the delay they have suffered on account of the activities referred to is at least equal to that period" (para. 46). Although invoked in the proceedings by the parties, art.2(4) of Directive 76/207/EEC was not explicitly relied upon by the Court itself. This may be explained by the fact that, contrary to what is envisaged by that provision, the contested provision of the Legal Training Regulations of the Land of Hesse did not provide for a form of affirmative action in favour of men, but rather exempted from a waiting period for access to legal training if the number of applications for admission to practical legal training exceeded the number of available training places those for whom this would result in an "undue hardship", including those who were required to perform military or civilian service. 


\begin{tabular}{|c|c|c|}
\hline Case & $\begin{array}{l}\text { Substance of } \begin{array}{r}\text { the } \\
\text { national provision at } \\
\text { stake }\end{array} \\
\end{array}$ & $\begin{array}{l}\text { Conclusions of the European } \\
\text { Court of Justice / EFTA } \\
\text { Court }\end{array}$ \\
\hline $\begin{array}{l}\text { Kalanke } \\
17 \text { October } \\
1995 \\
\text { C-450/93 }\end{array}$ & $\begin{array}{l}\text { Equally qualified women } \\
\text { are automatically given } \\
\text { priority in appointments } \\
\text { in sectors where they are } \\
\text { under-represented (1990 } \\
\text { Bremen Law on Equal } \\
\text { Treatment for Men and } \\
\text { Women in the Public } \\
\text { Service) }\end{array}$ & $\begin{array}{l}\text { An absolute and unconditional } \\
\text { priority for appointment or } \\
\text { promotion goes beyond } \\
\text { promoting equal opportunities } \\
\text { and oversteps the limits of the } \\
\text { exception in Article 2(4) of } \\
\text { Directive } 76 / 207 / E E C \text {. } \\
\text { A rule seeking to achieve equal } \\
\text { representation of men and } \\
\text { women in all grades and levels } \\
\text { within a department substitutes } \\
\text { for equality of opportunity as } \\
\text { envisaged in Article 2(4) the } \\
\text { result which is only to be } \\
\text { arrived at by providing such } \\
\text { equality of opportunity. }\end{array}$ \\
\hline $\begin{array}{l}\text { Marschall } \\
11 \text { Nov } 1997 \\
\text { C-409/95 }\end{array}$ & $\begin{array}{l}\text { Where there are fewer } \\
\text { women than men at the } \\
\text { level of the relevant post } \\
\text { in a sector of the public } \\
\text { service and both female } \\
\text { and male candidates for } \\
\text { the post are equally } \\
\text { qualified in terms of their } \\
\text { suitability, competence } \\
\text { and professional } \\
\text { performance, priority is to } \\
\text { be given to the promotion } \\
\text { of female candidates } \\
\text { unless reasons specific to } \\
\text { an individual male } \\
\text { candidate tilt the balance } \\
\text { in his favour (Law on } \\
\text { Civil Servants of the Land } \\
\text { Nordrhein-Westfalen } \\
\text { (1981, rev 1995)) }\end{array}$ & $\begin{array}{l}\text { A national rule in terms of } \\
\text { which female candidates for } \\
\text { promotion who are equally as } \\
\text { qualified as the male candidates } \\
\text { are to be treated preferentially } \\
\text { in sectors where they are under- } \\
\text { represented may fall within the } \\
\text { scope of Article 2(4) if such a } \\
\text { rule may counteract the } \\
\text { prejudicial effects on female } \\
\text { candidates of the attitudes and } \\
\text { behaviour towards women and } \\
\text { thus reduce actual instances of } \\
\text { inequality which may exist in } \\
\text { the real world; such a rule is not } \\
\text { disproportionate if, in each } \\
\text { individual case, it provides for } \\
\text { male candidates who are } \\
\text { equally as qualified as the } \\
\text { female candidates a guarantee } \\
\text { that the candidatures will be the } \\
\text { subject of an objective } \\
\text { assessment which will take } \\
\text { account of all criteria specific to } \\
\text { the individual candidates and } \\
\text { will override the priority } \\
\text { accorded to female candidates } \\
\text { where one or more of those } \\
\text { criteria tilts the balance in } \\
\text { favour of the male candidate, }\end{array}$ \\
\hline
\end{tabular}




\begin{tabular}{|c|c|c|}
\hline & & $\begin{array}{l}\text { provided those criteria do not } \\
\text { discriminate against female } \\
\text { candidates. }\end{array}$ \\
\hline \multirow[t]{2}{*}{$\begin{array}{l}\text { Badeck } \\
28 \text { March } \\
2000 \\
\text { C-158/97 }\end{array}$} & $\begin{array}{l}\text { "Flexible result quota" } \\
\text { (flexible Ergebnisquote) } \\
\text { system under which the } \\
\text { binding targets are } \\
\text { defined in accordance } \\
\text { with the specificities of } \\
\text { the sectors/ departments } \\
\text { concerned and which does } \\
\text { not necessarily determine } \\
\text { from the outset - } \\
\text { automatically - that the } \\
\text { outcome of each selection } \\
\text { procedure must, in a } \\
\text { stalemate situation where } \\
\text { the candidates have equal } \\
\text { qualifications, necessarily } \\
\text { favour the woman } \\
\text { candidate (Law of the } \\
\text { Land of Hesse on equal } \\
\text { rights for women and men } \\
\text { and the removal of } \\
\text { discrimination against } \\
\text { women in the public } \\
\text { administration (21 } \\
\text { December 1993), valid for } \\
13 \text { years). }\end{array}$ & $\begin{array}{l}\text { Article } 2(1) \text { and (4) of the } \\
\text { Directive does not preclude a } \\
\text { national rule which, in sectors } \\
\text { of the public service where } \\
\text { women are under-represented, } \\
\text { gives priority, where male and } \\
\text { female candidates have equal } \\
\text { qualifications, to female } \\
\text { candidates where that proves } \\
\text { necessary for ensuring } \\
\text { compliance with the objectives } \\
\text { of the women's advancement } \\
\text { plan, if no reasons of greater } \\
\text { legal weight are opposed, } \\
\text { provided that that rule } \\
\text { guarantees that candidatures are } \\
\text { the subject of an objective } \\
\text { assessment which takes account } \\
\text { of the specific personal } \\
\text { situations of all candidates }\end{array}$ \\
\hline & $\begin{array}{l}\text { National rule which } \\
\text { prescribes that the binding } \\
\text { targets of the women's } \\
\text { advancement plan for } \\
\text { temporary posts in the } \\
\text { academic service and for } \\
\text { academic assistants must } \\
\text { provide for a minimum } \\
\text { percentage of women } \\
\text { which is at least equal to } \\
\text { the percentage of women } \\
\text { among graduates, holders } \\
\text { of higher degrees and } \\
\text { students in each } \\
\text { discipline. }\end{array}$ & $\begin{array}{l}\text { Justified insofar as such a } \\
\text { system does not fix an absolute } \\
\text { ceiling but fixes one by } \\
\text { reference to the number of } \\
\text { persons who have received } \\
\text { appropriate training, which } \\
\text { amounts to using an actual fact } \\
\text { as a quantitative criterion for } \\
\text { giving preference to women }\end{array}$ \\
\hline & $\begin{array}{l}\text { National rule for the } \\
\text { public service which, in } \\
\text { trained occupations in } \\
\text { which women are under- } \\
\text { represented and for which } \\
\text { the State does not have a }\end{array}$ & $\begin{array}{l}\text { The provision forms part of a } \\
\text { restricted concept of equality of } \\
\text { opportunity: it is not places in } \\
\text { employment which are reserved } \\
\text { for women but places in } \\
\text { training with a view to }\end{array}$ \\
\hline
\end{tabular}




\begin{tabular}{|c|c|c|}
\hline & $\begin{array}{l}\text { monopoly of training, } \\
\text { allocates at least half the } \\
\text { training places to women, } \\
\text { unless if, despite } \\
\text { appropriate measures for } \\
\text { drawing the attention of } \\
\text { women to the training } \\
\text { places available, there are } \\
\text { not enough applications } \\
\text { from women, in which } \\
\text { case it is possible for } \\
\text { more than half of those } \\
\text { places to be taken by men. }\end{array}$ & $\begin{array}{l}\text { obtaining qualifications with } \\
\text { the prospect of subsequent } \\
\text { access to trained occupations in } \\
\text { the public service; since the } \\
\text { quota applies only to training } \\
\text { places for which the State does } \\
\text { not have a monopoly, and } \\
\text { therefore concerns training for } \\
\text { which places are also available } \\
\text { in the private sector, no male } \\
\text { candidate is definitively } \\
\text { excluded from training. }\end{array}$ \\
\hline & $\begin{array}{l}\text { National rule which } \\
\text { guarantees, where male } \\
\text { and female candidates } \\
\text { have equal qualifications, } \\
\text { that women who are } \\
\text { qualified are called to } \\
\text { interview, in sectors in } \\
\text { which they are under- } \\
\text { represented. }\end{array}$ & $\begin{array}{l}\text { The provision at issue in the } \\
\text { main proceedings does not } \\
\text { imply an attempt to achieve a } \\
\text { final result - appointment or } \\
\text { promotion - but affords women } \\
\text { who are qualified additional } \\
\text { opportunities to facilitate their } \\
\text { entry into working life and their } \\
\text { career. }\end{array}$ \\
\hline $\begin{array}{l}\text { Abrahamsson } \\
6 \text { July } 2000 \\
\text { C-407/98 }\end{array}$ & $\begin{array}{l}\text { A candidate belonging to } \\
\text { an under-represented sex } \\
\text { and possessing sufficient } \\
\text { qualifications for the post } \\
\text { may be chosen in } \\
\text { preference to a candidate } \\
\text { belonging to the opposite } \\
\text { sex who would otherwise } \\
\text { have been chosen, } \\
\text { provided that the } \\
\text { difference in their } \\
\text { respective qualifications } \\
\text { is not so great that } \\
\text { application of the rule } \\
\text { would be contrary to the } \\
\text { requirement of objectivity } \\
\text { in the making of } \\
\text { appointments } \\
\text { (Jämställdhetslagen } \\
\text { (1991:433) (Swedish Law } \\
\text { on equality) and } \\
\text { Högskoleförordningen } \\
\text { (1993:100) (Swedish } \\
\text { Regulation on } \\
\text { universities)) on }\end{array}$ & $\begin{array}{l}\text { The scope and effect of the } \\
\text { condition according to which } \\
\text { the difference between the } \\
\text { merits of the candidates of each } \\
\text { sex is not so great as to result in } \\
\text { a breach of the requirement of } \\
\text { objectivity in making } \\
\text { appointments cannot be } \\
\text { precisely determined, with the } \\
\text { result that the selection of a } \\
\text { candidate from among those } \\
\text { who are sufficiently qualified is } \\
\text { ultimately based on the mere } \\
\text { fact of belonging to the under- } \\
\text { represented sex, and that this is } \\
\text { so even if the merits of the } \\
\text { candidate so selected are } \\
\text { inferior to those of a candidate } \\
\text { of the opposite sex. Moreover, } \\
\text { candidatures are not subjected } \\
\text { to an objective assessment } \\
\text { taking account of the specific } \\
\text { personal situations of all the } \\
\text { candidates. It follows that such } \\
\text { a method of selection is not } \\
\text { such as to be permitted by } \\
\text { Article 2(4) of the Directive. }\end{array}$ \\
\hline
\end{tabular}




\begin{tabular}{|c|c|c|}
\hline $\begin{array}{l}\text { Schnorbus } 7 \\
\text { Dec } 2000 \text { C- } \\
79 / 99\end{array}$ & $\begin{array}{l}\text { Where a decision } \\
\text { concerning the admission } \\
\text { of applicants to practical } \\
\text { legal training is required } \\
\text { because the number of } \\
\text { applicants exceeds the } \\
\text { number of training places, } \\
\text { an applicant who has } \\
\text { completed service which } \\
\text { is obligatory only for men } \\
\text { (military or substitute } \\
\text { service pursuant to Article } \\
\text { 12a of the Grundgesetz) is } \\
\text { to be immediately } \\
\text { admitted to the training } \\
\text { and does not have to } \\
\text { satisfy any further } \\
\text { requirements in that } \\
\text { regard, whereas the } \\
\text { admission of other } \\
\text { applicants (female and } \\
\text { male) may be deferred by } \\
\text { up to } 12 \text { months. }\end{array}$ & $\begin{array}{l}\text { By giving priority to applicants } \\
\text { who have completed } \\
\text { compulsory military or civilian } \\
\text { service, the provisions at issue } \\
\text { themselves are evidence of } \\
\text { indirect discrimination since, } \\
\text { under the relevant national } \\
\text { legislation, women are not } \\
\text { required to do military or } \\
\text { civilian service and therefore } \\
\text { cannot benefit from the priority } \\
\text { accorded to those who have } \\
\text { completed service; however, the } \\
\text { provision at issue, which takes } \\
\text { account of the delay } \\
\text { experienced in the progress of } \\
\text { their education by applicants } \\
\text { who have been required to do } \\
\text { military or civilian service, is } \\
\text { objective in nature and } \\
\text { prompted solely by the desire to } \\
\text { counterbalance to some extent } \\
\text { the effects of that delay, } \\
\text { therefore it cannot be regarded } \\
\text { as contrary to the principle of } \\
\text { equal treatment for men and } \\
\text { women: the advantage } \\
\text { conferred on the persons } \\
\text { concerned, whose enjoyment of } \\
\text { priority may operate to the } \\
\text { detriment of other applicants } \\
\text { only for a maximum of } 12 \\
\text { months, is not disproportionate, } \\
\text { since the delay they have } \\
\text { suffered on account of the } \\
\text { activities referred to is at least } \\
\text { equal to that period. }\end{array}$ \\
\hline $\begin{array}{l}\text { Lommers, } 19 \\
\text { March 2002, } \\
\text { C-476/99 }\end{array}$ & $\begin{array}{l}\text { Scheme set up by a } \\
\text { Minister to tackle } \\
\text { extensive under- } \\
\text { representation of women } \\
\text { within his Ministry under } \\
\text { which a limited number of } \\
\text { subsidised nursery places } \\
\text { made available by the } \\
\text { Ministry to its staff is } \\
\text { reserved for female } \\
\text { officials alone whilst male } \\
\text { officials may have access } \\
\text { to them only in cases of } \\
\text { emergency, to be deter- }\end{array}$ & $\begin{array}{l}\text { Article } 2(1) \text { and (4) of the } \\
\text { Directive does not preclude a } \\
\text { scheme set up by a Ministry to } \\
\text { tackle extensive under- } \\
\text { representation of women within } \\
\text { it under which, in a context } \\
\text { characterised by a proven } \\
\text { insufficiency of proper, } \\
\text { affordable care facilities, a } \\
\text { limited number of subsidised } \\
\text { nursery places made available } \\
\text { by the Ministry to its staff is } \\
\text { reserved for female officials } \\
\text { alone whilst male officials may }\end{array}$ \\
\hline
\end{tabular}




\begin{tabular}{|c|c|c|}
\hline & mined by the employer. & $\begin{array}{l}\text { have access to them only in } \\
\text { cases of emergency, to be } \\
\text { determined by the employer, in } \\
\text { so far as the said exception in } \\
\text { favour of male officials is } \\
\text { construed as allowing those of } \\
\text { them who take care of their } \\
\text { children by themselves to have } \\
\text { access to that nursery places } \\
\text { scheme on the same conditions } \\
\text { as female officials. }\end{array}$ \\
\hline $\begin{array}{l}\text { EFTA Court, } \\
24 \text { January } \\
2003 \text {, E-1/02, } \\
\text { EFTA } \\
\text { Surveillance } \\
\text { Authority v } \\
\text { Norway }\end{array}$ & $\begin{array}{l}\text { Permanent and temporary } \\
\text { academic positions ear- } \\
\text { marked for women either } \\
\text { by direction of the } \\
\text { Norwegian Government } \\
\text { or by the University of } \\
\text { Oslo }\end{array}$ & $\begin{array}{l}\text { The Norwegian legislation in } \\
\text { question must be regarded as } \\
\text { going beyond the scope of } \\
\text { Article 2(4) of the Directive, } \\
\text { insofar as it permits earmarking } \\
\text { of certain positions for persons } \\
\text { of the underrepresented gender. } \\
\text { The last sentence of Article } \\
30(3) \text { of the University Act as } \\
\text { applied by the University of } \\
\text { Oslo gives absolute and } \\
\text { unconditional priority to female } \\
\text { candidates. There is no } \\
\text { provision for flexibility, and the } \\
\text { outcome is determined } \\
\text { automatically in favour of a } \\
\text { female candidate. }\end{array}$ \\
\hline $\begin{array}{l}\text { Briheche, } \\
\text { 30 September } \\
\text { 2004, C- } \\
319 / 03\end{array}$ & $\begin{array}{l}\text { Legislation reserving to } \\
\text { "widows who have not } \\
\text { remarried" the benefit of } \\
\text { the exemption from the } \\
\text { age limit (45 years) for } \\
\text { obtaining access to } \\
\text { public-sector } \\
\text { employment, excluding } \\
\text { widowers from the same } \\
\text { advantage }\end{array}$ & $\begin{array}{l}\text { Such a provision automatically } \\
\text { and unconditionally gives } \\
\text { priority to the candidatures of } \\
\text { certain categories of women, } \\
\text { including widows who have not } \\
\text { remarried who are obliged to } \\
\text { work, reserving to them the } \\
\text { benefit of the exemption from } \\
\text { the age limit for obtaining } \\
\text { access to public-sector } \\
\text { employment and excluding } \\
\text { widowers who have not } \\
\text { remarried who are in the same } \\
\text { situation, which cannot be } \\
\text { allowed under Article 2(4) of } \\
\text { the Directive } 76 / 207 / \mathrm{EEC}\end{array}$ \\
\hline
\end{tabular}

Although the assessment which the Court of Justice has given of the various national rules that were submitted to it in the cases listed above may seem hard to reconcile with each other, the general significance of the Court's 
approach seems fairly clear. This approach appears to be based on the idea that affirmative action in favour of women aimed at achieving equal "opportunity" for men and women, cannot go beyond this objective and pursue equal "results". The latter objective would be contrary to the principle of equal treatment whereby each person has the right not to be disadvantaged on grounds of his or her sex. According to the interpretation given by the Court, this limit is exceeded when affirmative action gives preference to women in the acquisition of a result (access to employment, obtaining a promotion) which has an absolute character, that is to say, which does not allow the rejected male candidate to bring forward the arguments that are likely to tilt the balance in his favour. Absolute preference in this sense would be considered discriminatory, since it establishes a non-rebuttable presumption in favour of women in cases where the candidates from both sexes are equally qualified, unless it is based on an "actual fact" such as the proportion of men and women among the persons with such a qualification. On the other hand, the preferential treatment that is accorded to women in terms of access to certain opportunities (vocational training, calls to job interviews) will be considered with less severity: even when absolute, such preferential treatment is aimed at achieving equal opportunity for men and women, and on this account should be considered as covered by the exception provided for in Article 2 (4) of Directive 76/207/EEC. Upon closer examination however, the distinction between equality of opportunities and equality of results to which the Court attaches so much importance - and for which there is some textual support in Article 2(4) of Directive 76/207/EEC - is not particularly helpful. It may even be a source of confusion, as it is used interchangeably either to distinguish measures which seek to provide chances to women from measures which seek to guarantee an outcome, ${ }^{118}$ or to distinguish measures which improve the access of women to training positions which prepare for the competition on the employment market from measures which favour women in the allocation of jobs proper. ${ }^{119}$

118 This is how the distinction was understood in Kalanke. In Badeck, both Advocate General A. Saggio, in para.41 of his opinion, and the Court considered that a national rule which guarantees, where male and female candidates have equal qualifications, that women who are qualified are called to interview, in sectors in which they are under-represented, "does not imply an attempt to achieve a final result - appointment or promotion - but affords women who are qualified additional opportunities to facilitate their entry into working life and their career" (para.60 of the judgment).

119 In Badeck, the Court agreed that a national rule for the public service which, in trained occupations in which women are under-represented and for which the State does not have a monopoly of training, allocates at least half the training places to women, was acceptable under art.2(4) of Directive 76/207/EEC. It noted in that respect that the challenged provision "forms part of a restricted concept of equality of opportunity. It is not places in employment which are reserved for women but places in training with a view to obtaining qualifications with the prospect of subsequent access to trained occupations in the public service" (para.52). The EFTA Court thus considers that the European Court of Justice has "drawn a distinction between training for employment and actual places in employment. With regard to training positions, it has relied on a restricted concept of equality of opportunity allowing the reservation of positions for women, with a view to obtaining qualifications necessary for subsequent access 
Another - and in my view more fruitful - way to approach the case-law of the Court of Justice in the affirmative action cases it has been presented with, is by locating it within the framework outlined above. ${ }^{120}$ If we consider, first, the three possible justifications for the adoption of affirmative action measures (backward-looking or compensatory for past discrimination; as a tool to remove actual inequalities in fact; or forward-looking and aiming at proportionate representation or diversity), it appears clearly that only the second rationale has been considered to date legitimate by the Court: the Court reads Article 2(4) of Directive 76/207/EEC as "specifically and exclusively designed to authorise measures which, although discriminatory in appearance, are in fact intended to eliminate or reduce actual instances of inequality which may exist in the reality of social life". ${ }^{121}$ The Court considers, thus, that only actual inequalities in opportunity may render legitimate the use of affirmative action measures, as a restriction to the individual right to equal treatment. This may have seemed initially to the Court to be dictated by the language of Article 2(4) of Directive 76/207/EEC, which refers to "removing existing inequalities which affect women's opportunities". ${ }^{122}$ However, despite the more encouraging formulation of Article 141(4) EC as inserted in the Treaty of Rome by the Treaty of Amsterdam, ${ }^{123}$ the Court seems now to hold to this argument even without firm textual support. ${ }^{124}$

The Court also considers that any affirmative action measure seeking to eliminate or reduce actual instances of inequality should be strictly proportionate to that end. This is the source of its suspicion towards rules guaranteeing preferential treatment to women which are absolute and unconditional, i.e. which do not provide for the possibility to objectively assess all competing candidates in order to take into account their specific personal situations. This is also why, for instance, the Court did not object in

to trained occupations in the public service" (para.50). However, as the EFTA Court also rightly notes, this qualification by the European Court of Justice of a measure as relating to equality of opportunity does not exempt this measure from being examined for its compliance with the requirement of proportionality: "even for training positions, the law requires a system that is not totally inflexible" (para.50).

120 Supra, s.4.1.

121 Kalanke, para.18 (citing Case 312/86 Commission v France [1988] ECR 6315, paragraph 15); Marschall, para.26; Badeck, para.19. The emphasis is added.

122 Emphasis added.

123 Article 141(4) EC refers to "measures providing for specific advantages in order to make it easier for the under-represented sex to pursue a vocational activity or to prevent or compensate for disadvantages in professional careers". This would seem to allow for measures seeking to remedy the impacts of past discrimination towards women (which, for instance, may explain the lack of representation of women in certain sectors), by achieving a distribution "representing a (. . .) level of equality of representation that women would have had in the absence of societal discrimination" (Kenner, EU Employment Law (2003) 451), as well as measures which seek to anticipate the risk that women will be treated less favourably in the absence of affirmative action, even where such risk is not proven to have materialized yet.

124 See Abrahamsson, paras.54-55 (where the Court appears to consider that a measure found disproportionate under arts.2(1) and (4) of Directive 76/207/EEC also would fail to be justified under art.141(4) EC). 
Badeck to a national rule for the public service which, in trained occupations in which women are under-represented and for which the State does not have a monopoly of training, allocates at least half the training places to women, on the basis that "the quota applies only to training places for which the State does not have a monopoly, and therefore concerns training for which places are also available in the private sector, [so that] no male candidate is definitively excluded from training". ${ }^{25}$ Many other examples could be given. What matters is that the requirement of proportionality imposed by the Court is in fact interpreted to ensure that the affirmative action measures developed by the Member States do not sacrifice individual justice (the right of each individual to be treated on the basis of his or her personal situation) in the name of group justice (the automatic and absolute preference given to the members of one group, e.g. women, simply because of that membership).

\subsection{The future of affirmative action jurisprudence}

How, then, may this case-law develop, when transposed to the new grounds of prohibited discrimination listed under Article $13 \mathrm{EC}$, and when applied to affirmative action measures developed in fields other than employment? Each of the Directives adopted on the basis of Article 13 EC provides, "With a view to ensuring full equality in professional life [or, more generally, in practice], the principle of equal treatment shall not prevent any Member State from maintaining or adopting specific measures to prevent or compensate for disadvantages linked to any of the grounds [such as racial or ethnic origin]". ${ }^{126}$ When it proposed the insertion of these clauses in the directives, the Commission seemed to assume that the case-law of the European Court of Justice as it had begun to develop with Kalanke and Marschall would simply apply, mutatis mutandis, to the new grounds of prohibited discrimination. ${ }^{127}$ However, apart from the obvious differences which exist between the criterion of sex, on the one hand, and those of race or ethnic origin, religion or belief, age, sexual orientation or disability on the other hand - as well as, indeed, among these different "new" grounds of prohibited discrimination themselves - both with respect to the visibility or invisibility of these different criteria and the objectivity with which they may be ascertained, the gap is considerable between the questions which the Court has confronted hitherto and the challenges which lie ahead.

(a) Beyond the promotion of equal treatment between women and men

Note, first, that while it has proven to be relatively open to the judgment of legislatures of the Member States according to which affirmative action measures in favour of women were required to move beyond merely formal equality, the European Court of Justice has never considered that the Member States may be required to adopt such measures in order to implement the principle of equal treatment. In the case presented to the EFTA Court, the Kingdom of Norway sought to justify a rule reserving a

25 Badeck, para.53.

126 Art.7(1) of the Employment Equality Directive; art.5 of the Racial Equality Directive.

127 See COM(1999) 565 final, of 25.11.1999, at p.11: "as positive action measures are a derogation from the principle of equality, they should be interpreted strictly, in the light of the current case-law on sex discrimination". 
number of academic posts exclusively for women by the requirements of the 1979 International Convention on the Elimination of All Forms of Discrimination against Women (CEDAW). This argument was dismissed by the EFTA Court, on the ground that neither the CEDAW, nor other international instruments dealing with affirmative action measures in various circumstances, impose on States parties an obligation to adopt such measures: with respect to affirmative action, these instruments are "permissive rather than mandatory". ${ }^{128}$

Things may not be so simple, however, once we extend the question beyond affirmative action in favour of women. Under the International Covenant on Civil and Political Rights, the UN Human Rights Committee noted that "the principle of equality sometimes requires States parties to take affirmative action in order to diminish or eliminate conditions which cause or help to perpetuate discrimination prohibited by the Covenant. For example, in a State where the general conditions of a certain part of the population prevent or impair their enjoyment of human rights, the State should take specific action to correct those conditions. Such action may involve granting for a time to the part of the population concerned preferential treatment in specific matters as compared with the rest of the population. However, as long as such action is needed to correct discrimination in fact, it is a case of legitimate differentiation under the Covenant." 129 Article 2(2) of the 1965 International Convention on the Elimination of All Forms of Racial Discrimination, ${ }^{130}$ which is another instrument which all the EU Member States have ratified, provides that:

"States Parties shall, when the circumstances so warrant, take, in the social, economic, cultural and other fields, special and concrete measures to ensure the adequate development and protection of certain racial groups or individuals belonging to them, for the purpose of guaranteeing them the full and equal enjoyment of human rights and fundamental freedoms. These measures shall in no case entail as a consequence the maintenance of unequal or separate rights for different racial groups after the objectives for which they were taken have been achieved."

This provision, it will be noted, is more precise than its equivalent in the CEDAW (Article 3), which the EFTA Court probably had in view, together with Article 4(1), when it delivered its judgment in Case E-1/02. Both the ICERD and the CEDAW also contain clauses allowing for the adoption of affirmative action measures, provided these measures do not entail as a consequence the maintenance of unequal or separate rights or standards, and

128 Case E-1/02, EFTA Surveillance Authority v Kingdom of Norway (judgment of 24 January 2003), para.58.

129 Human Rights Committee, General Comment No.18: Non-discrimination (1989), in Compilation of the General Comments or General Recommendations adopted by Human Rights Treaty Bodies, UN doc. HRI/GEN/1/Rev7, 12 May 2004, at p.146, para. 10 .

130 The International Convention on the Elimination of All Forms of Racial Discrimination was adopted and opened for signature and ratification by General Assembly resolution 2106 (XX) of 21 December 1965. It entered into force 4 January 1969. 
that such measures shall be discontinued after the objectives of equality of opportunity and treatment have been achieved. ${ }^{131}$ However, the wording of Article 2(2) ICERD suggests that the adoption of affirmative action measures may in certain cases be compulsory, rather than simply optional, in circumstances where a particular racial or ethnic group is subjected to a form of structural discrimination. ${ }^{132}$ Similar positive obligations to adopt measures in the face of entrenched inequalities may be derived from the Council of Europe Framework Convention on the Protection of National Minorities. Under Article 4 of the Framework Convention, States parties are to adopt "adequate measures in order to promote, in all areas of economic, social, political and cultural life, full and effective equality between persons belonging to a national minority and those belonging to the majority", taking due account in this respect of "the specific conditions of the persons belonging to national minorities"; such measures are specifically designated as not being discriminatory in character. The Advisory Committee of the Framework Convention encourages the introduction of positive measures in favour of members of minorities, which are particularly disadvantaged. ${ }^{133}$ With respect to persons with disabilities, the UN Committee on Economic, Social and Cultural Rights has considered, in its General Comment No. 5 on persons with disabilities, that the obligation imposed on the States parties to progressively realize the rights of the International Covenant on Economic, Social and Cultural Rights to the maximum of their available resources extends "in the case of such a vulnerable and disadvantaged group" to the obligation "to take positive action to reduce structural disadvantages and to give appropriate preferential treatment to people with disabilities in order to achieve the objectives of full participation and equality within society for all persons with disabilities. This almost invariably means that additional resources will need to be made available for this purpose and that a wide range of specially tailored measures will be required". ${ }^{134}$ Therefore, it may

131 Art.4(1) CEDAW; art.1(4) ICERD.

132 Where it states that the States parties to the ICERD should "take special measures to promote the employment of Roma in the public administration and institutions, as well as in private companies", and "adopt and implement, whenever possible, at the central or local level, special measures in favour of Roma in public employment such as public contracting and other activities undertaken or funded by the Government (. . .)", the Committee on the Elimination of Racial Discrimination may be implicitly referring to the obligations of the States parties under art.2(2) ICERD. See Committee on the Elimination of Racial Discrimination, General Recommendation 27, Discrimination against Roma, (Fifty-seventh session, 2000), U.N. Doc. A/55/18, annex V at 154 (2000), reprinted in Compilation of General Comments and General Recommendations Adopted by Human Rights Treaty Bodies, UN Doc. HRIIGEN\1\Rev6 at 216 (2003), at paras.27-28. See also O. De Schutter and A. Verstichel, "The Role of the Union in Integrating the Roma: Present and Possible Future", European Diversity and Autonomy Papers (EDAP) 2/2005, 37 available at www.eurac.edu/edap.

133 See, e.g. Opinion on Azerbaijan, 22 May 2003, ACFC/OP/I(2004)001, para.28; Opinion on Ukraine, 1 March 2002, ACFC/OP/I(2002)010, para.27; Opinion on Serbia and Montenegro, 27 November 2003, ACFC/OP/I(2004)002, para.38.

134 UN Committee on Economic, Social and Cultural Rights, General Comment n.5: Persons with disabilities, adopted at its 11th session (1994) (UN doc. E/1995/22), para.9. 
be easier for the Member States to justify certain affirmative action measures benefiting racial or ethnic minorities, or religious minorities, than it has been to justify similar measures adopted in order to promote the professional integration of women. ${ }^{135}$

\section{(b) Beyond the promotion of equal treatment in the sphere of employment}

This first remark relates to the transposition of a case-law developed with respect to affirmative action measures benefiting women, to similar measures benefiting other groups which have been traditionally subject to discrimination and to the members of which the Racial Equality Directive and the Employment Equality Directive have extended the principle of equal treatment. A second challenge concerns the transposition of a case-law developed in the field of employment to other domains, covered by Article 3 of the Racial Equality Directive ${ }^{136}$ or, more recently, by Article 3 of Council Directive 2004/113/EC of 13 December 2004 implementing the principle of equal treatment between men and women in the access to and supply of goods and services. ${ }^{137}$ By moving in this direction, we move from one sphere of justice, to use the terminology of Walzer, ${ }^{138}$ to other spheres. This should profoundly affect our understanding of the legitimacy of affirmative

135 Although it is easy to make the case that affirmative action is not per se contrary to international law, the question whether affirmative action may be mandatory in certain circumstances remains debated. Comp. "The concept and practice of affirmative action”, Final report submitted by Mr. Marc Bossuyt, supra n.98, at para.53 (noting that "neither of the Covenants [ICCPR and ICESCR] has explicitly recognized any obligatory nature of affirmative action"), with M. Craven, The International Covenant on Economic, Social and Cultural Rights, a perspective on its development, Oxford, Clarendon Press, 1995, p.126 (emphasizing the obligation of States to focus their efforts on the most vulnerable and disadvantaged groups in society, which may include preferential treatment in favour of the members of these disadvantaged groups). In the conclusions of his report, M. Bossuyt notes however that "a persistent policy in the past of systematic discrimination of certain groups of the population may justify - and in some cases may even require - special measures intended to overcome the sequels of a condition of inferiority which still affects members belonging to such groups" (at para.101 (emphasis added)).

136 Supra, nn. 13-15 and the corresponding text.

137 Art.4(5) of this Directive provides that it "shall not preclude differences in treatment, if the provision of the goods and services exclusively or primarily to members of one sex is justified by a legitimate aim and the means of achieving that aim are appropriate and necessary". The dissimilarity in wording illustrates that the authors of the directive are aware of the difficulties of transposing, mutatis mutandis, the existing case-law of the European Court of Justice as developed in the field of employment to the access to and supply of goods and services. The Preamble of the Directive (16th Recital) nevertheless states that "Differences in treatment may be accepted only if they are justified by a legitimate aim. (. . .). Any limitation should nevertheless be appropriate and necessary in accordance with the criteria derived from case law of the Court of Justice of the European Communities". The examples referred to however do not include affirmative action policies in the access to or provision of goods and services.

138 M. Walzer, Spheres of Justice. A Defense of Pluralism and Equality, New York, Basic Books, 1983. 
action, and thus, of its legal admissibility. By situating ourselves in one sphere, we are led to rely, more or less spontaneously, on a particular criterion of allocation which is imposed by the very nature of the good to be distributed. In the sphere of employment for instance, jobs will be distributed according to professional qualifications through the means of recruitment procedures, whereas protection from dismissal will be defined according to seniority, ${ }^{139}$ and intra-firm promotions will generally be decided on the basis of a combination of these two criteria. Similarly, just like the academic grade will be granted according to the achievements of the candidate and the allocation of certain minimum social benefits will be granted according to the needs of the individual, the grant of a study scholarship will be decided upon through a combination of these two variables. As to the allocation of a subsidized home, it may depend on the needs of the family which has introduced the request, but also on the date on which the request has been filed - priority may be given to the requests which have been filed first, so that the families having waited for the longest period will be rewarded before the more recent requests are satisfied - and perhaps on the need to preserve a certain social or ethnic mix in the distribution of social housing and thus to avoid phenomena of segregation or ghettoization. Such examples could of course be multiplied.

These phenomena of "local justice" illustrate the extent to which an acceptable justification for the allocation of scarce goods will depend on the sphere in which we are situated. ${ }^{140}$ The relevance of this notion to the debate on affirmative action should be obvious. First, it illustrates that the use of affirmative action may be acceptable in a particular sphere, but may nevertheless be excluded in another sphere to ensure the allocation of another scarce social good: thus, the need to preserve a representation of all the cultural groups of a society in the audio-visual programs may justify certain restrictions to the principle of non-discrimination, ${ }^{141}$ although a similar requirement would not be acceptable, for instance, in the context of recruitment processes in employment; and an affirmative action programme acceptable at the recruitment stage could be less acceptable in determining

139 S. Romm, "Layoffs: Principles and Practices", in J. Elster (ed.), Local Justice in America, New York: Russell Sage Foundation, 1995, pp.153-226, at p.155.

140 See L. Boltanski et L. Thévenot, De la justification. Les économies de la grandeur, Paris, Gallimard, 1991. See already, by the same authors: Les économies de la grandeur, Paris, Centre d'études sur l'emploi, Presses universitaires de France, 1987.

141 In a case where a national legislation was challenged on the basis of the rules of the Treaty of Rome on the free movement of capital and the free provision of services, the European Court of Justice agreed that the need to safeguard, in the audiovisual sector, the freedom of expression of the different components, notably social, cultural, religious or philosophical, of society, should be considered a legitimate objective: see Case 353/89, Commission v the Netherlands, ECR [1991] 4089, para.30; and Case 288/89, Stichting Collectieve Antennevoorziening Gouda and others v Commissariaat voor de Media, ECR [1991] 4007, para.23. However, the obligation imposed on the national organisations of radio broadcasting to ensure that the different social, cultural, religious or philosophical components of Dutch society are represented in their programmes through a national undertaking, the Bedrijf, was considered disproportionate to the objective pursued. 
the order of layoffs, in collective layoff procedures. ${ }^{142}$ It is therefore extremely difficult to establish admissibility criteria of affirmative action that can claim general validity, that is, criteria that are not strictly linked not only to a particular "sphere" such as employment or education, but also to certain specific contexts such as, for instance, the size of a company, or the kind of market - local, national or global - where it sells its products. The identification of general criteria would be all the more difficult if, as the case of the allocation of scholarships or social housing illustrates, social goods would have to be distributed frequently according to a combination of criteria, rather than according to one single metric.

Although the possible assessment of affirmative action thus strictly depends on the nature of social goods of which the distribution is at stake, it would be wrong to consider that the environment in which we find ourselves predetermines the nature of the justification criteria of the distributions that take place there. Which kind of "local justice" predominates in a particular field depends on social expectations; these may change, and such change, far from being predominantly spontaneous, is in many cases the result of the artificial reshaping of social institutions, in which legal regulation itself has an important role to play. Is it necessarily true, for instance, that a company has no other objective than to make profit, and is it therefore normally inadmissible, except when relying on particularly solid justifications, to demand that a company departs from the principle of employment merely on the basis of the expected productivity of the candidates who present themselves? Should we not, on the contrary, consider that the company must contribute, like all the other social players, whether economic or not, to the integration of certain traditionally excluded sections of the population in the employment market - in exactly the same way as we should ascribe to an allocation system for social housing the objective of meeting the "needs" that arise according to their degree of urgency, but also of contributing to the social or ethnic mixity of neighbourhoods? We see here the danger that lies in a purely instrumental approach to the question of affirmative action that merely asks itself whether the end pursued by such a policy (integration of the beneficiary group) can justify a departure from the allocation principle that should normally govern such an area, in accordance with the rule of nondiscrimination. The question arises whether this allocation principle is as imperative as it appears to be, or whether, by treating it with such deference, we are not guilty of a kind of institutional fetishism which constitutes an unnecessary obstacle to a reflection on affirmative action.

This may be illustrated by the role which the notions of "merit" or "qualifications" have hitherto played in the case-law of the European Court of Justice. These notions operate to form the baseline of the Court's reasoning in affirmative action cases: procedures or criteria which reward "qualifications" relevant for the job are in principle valid, any measures

142 See, e.g. Wygant $\mathrm{v}$ Jackson Bd of Educ., 476 U.S. 267 (1986). Thus according to R. B. Ginsburg and D. J. Merritt, "The concern that affirmative action plans do not trench heavily on settled expectations has been salient in U.S. affirmative action jurisprudence. Thus preferences permissible for hiring have been rejected when laying off workers is the issue; for layoffs, strict seniority systems prevail" (R.B. Ginsburg \& D.J. Merritt, "Affirmative Action: An International Human Rights Dialogue”, 21 Cardozo L. Rev 253 (1999), at 265). 
which seek to derogate from this baseline in order to achieve social justice (specifically, to improve the representation of women) are only allowable if they comply with the principle of proportionality. Thus, while it claims to combat certain effects resulting from the reliance on the mechanisms through which the market allocates its rewards to the individuals, affirmative action seems to acknowledge, without radically challenging it, the neutrality of these mechanisms. The technique of affirmative action allocates the roles. It is the role of market mechanisms to identify the "merits" and "skills"; in short, to locate the "most qualified". The instrument of law is then given the task of derogating from the outcome of these identifications, in order to accord "preferential" treatment to certain disadvantaged groups on account of the characteristics presented by its members. ${ }^{143}$ Affirmative action thus, far from subverting the dominant logic - the idea that the market will reward the most "qualified" - may in fact reinforce it. As a result, the members of disadvantaged groups may find the negative stereotypes that exist with respect to them being further strengthened from the moment the law intervenes to compensate for the fact that they do not have - or are considered not to have - the qualities that would enable them to manage without its help.

A more subversive approach then may consist in going a step further, which is to challenge not only the consequences of the use of affirmative action, but also the very concept of "merit" - a concept which, convinced as we are of the natural character of the market mechanisms, we have such a strong tendency to turn into a fetish. The Badeck case precisely offers an illustration of the results which such an approach may lead to. The law of the Land of Hesse that was submitted to the Court of Justice in this case comprised a provision (paragraph 10) which stipulated: "When qualifications are assessed, qualifications and experience which have been acquired by looking after children or persons requiring care in the domestic sector (family work) are to be taken into account, in so far as they are of importance for the suitability, performance and capability of applicants. That also applies where family work has been performed alongside employment". The Court noted that such criteria, "although formulated in terms which are neutral as regards sex and thus capable of benefiting men too, in general favour women", but that they are "manifestly intended to lead to an equality which is substantive rather than formal, by reducing the inequalities which may occur in practice in social life". ${ }^{144}$ It did not question their legitimacy. ${ }^{145}$ In similar fashion, when it was confronted with the set-aside in favor of

143 In the Abrahamsson judgment, which concerned the Swedish rule favouring the recruitment of women to university teaching posts, the Court of Justice of the European Communities clearly reasserted the principle: "As a rule, a procedure for the selection of candidates for a post involves assessment of their qualifications by reference to the requirements of the vacant post or of the duties to be performed" (Case C-407/98, Abrahamsson and others, para.46). It is significant that this assertion is made in a context where the Community court was asked to rule on the legitimacy of a recourse to positive action: its reasoning must be based on the initial position of a supposedly neutral concept of "merit", to the requirements of which affirmative action makes an exception.

144 Para.32.

145 The Court in fact did not have to adopt a position on the acceptability of these criteria, which the parties to the main proceedings did not challenge. 
women in Norwegian academia, the EFTA Court remarked that ". . . the criteria for assessing the qualifications of candidates are essential. In such an assessment, there appears to be scope for considering those factors that, on empirical experience, tend to place female candidates in a disadvantaged position in comparison with male candidates. Directing awareness to such factors could reduce actual instances of gender inequality. Furthermore, giving weight to the possibility that in numerous academic disciplines female life experience may be relevant to the determination of the suitability and capability for, and performance in, higher academic positions, could enhance the equality of men and women, which concern lies at the core of the Directive". ${ }^{146}$

This reflexive re-appropriation of the concepts of "merit" or "qualification" has far-reaching consequences. Instead of the content of these concepts being imposed on us from outside, like when they are presented as dictated by the "laws of the market", they are here normatively defined as the outcome of a democratic deliberation process. This is a positive development. It calls upon us not to fetishize the way in which the market distributes its rewards. These allocation rules which result from the mechanisms of the market are inherited from a not all that distant past when discrimination was not disapproved of as it is today. They reflect a multiplicity of individual preferences which cannot be assumed to be free from prejudice. Moreover, by critically reflecting upon the concept of merit, we create the possibility of taking into account certain qualities which these persons may have, although they generally do not benefit from institutional recognition. Where affirmative action generally seeks to compensate certain individuals solely on account of their belonging to a traditionally disadvantaged category, leaving unchallenged the background norms relating to "merit", we now call into question the natural character of the "laws" of the market themselves and of their "blind" operation, as well as their pretence to neutrality - and therefore, also of their claim to provide the reference against which any change is to be viewed precisely as a derogation.

And yet, there is at the same time a risk inherent in such attempts to reshape the content of the notions of "merit" or "qualification" which form the baseline of the affirmative action jurisprudence. The successive revisions of these concepts should not make us lose sight of the importance of creating the background conditions that will allow each individual, no matter what social group he or she belongs to, to meet the requirements that are uniformly imposed on all persons. If not, the very ambition of defining scales of abilities that are common to all will be abandoned, and any existing inequalities of opportunities at the start will be accepted, provided that in the end these inequalities can be compensated for and the consequences of the unequal distribution of endowments between different social groups, thereby, mitigated. ${ }^{147}$

We see, then, that there is a balance to be struck here between two concerns, which we should take as being complementary rather than contradictory. On

146 Para.57.

147 See in this sense R. H. Fallon, "To Each According to His Ability, From None According to His Race: The Concept of Merit in the Law of Antidiscrimination", Boston Univ L. Rev, vol. 60, 1980, p.815, here p.876. 
the one hand, we need to make our understanding of anti-discrimination law more reflexive, to revise our spontaneous interpretations of the concepts of "merit", "competence" or "qualification" based on the different meanings which those interpretations may contain. On the other hand, we need to make every effort to ensure that each person, no matter what category he or she belongs to, is equipped with the tools that will enable him/her to meet the requirements that these concepts designate. By losing sight of the latter objective, we will run the risk of substituting a constant renegotiation of the criteria of competence for a structural policy aimed at promoting equality of opportunity. The danger would be that the members of the groups for whose benefit this renegotiation takes place will no longer be tempted to invest in acquiring certain skills, and that eventually we will find ourselves moving yet further away from, instead of coming closer to, the utopian view of a society where social cohesion is sufficiently strong and reliance on market mechanisms will not lead to structural inequalities. Neither affirmative action, nor a revision of the concept of "qualifications" in order to defetichize the understanding of this concept which we tend to see as naturally dictated by the requirements of the marketplace, are adequate substitute for policies aiming at the removal of the conditions which create inequalities in opportunities in the first place - policies which, for example in the fields of childrearing and education, seek to facilitate the conciliation of working and family life, or which seek to modify the dominant stereotypes about the ability of women to compete on the marketplace.

For the future of affirmative action, beyond the use of this tool in order to accelerate the professional integration of women - the context in which the case-law of the European Court of Justice has hitherto been developing - the lessons are the following. Whether or not the Court will continue to adhere to this case-law, allowing affirmative action only in situations where "actual inequalities" are shown to exist which have to be removed or compensated for and subjecting affirmative action measures to the test of proportionality, one alternative to affirmative action which may have to be explored further consists in the redefinition of the criteria which usually are relied upon in order to allocate social goods, depending on the nature of these goods. Just like "qualifications" may be redefined to take into account the experience which may have been acquired by looking after children or persons requiring care in the domestic sector or the specific "female life experience", they may be rethought in order to take into account the specific value, both in private business and in the public sector, of including more minorities, in order to be more responsive to the needs of the clients or of the public. ${ }^{148}$ Similarly, in

148 Indeed, even specifically taking into account the race or ethnic origin, the religion or belief, disability, age or sexual orientation of the individual concerned may be acceptable and should not necessarily be construed as a prohibited form of direct discrimination. Both the Racial Equality Directive (art.4 and Recital 18 of the Preamble) and the Employment Equality Directive (art.4 (1) and Recital 23 of the Preamble) provide that a difference of treatment which is based on a suspect characteristic shall not constitute discrimination where, "by reason of the nature of the particular occupational activities concerned or of the context in which they are carried out, such a characteristic constitutes a genuine and determining occupational requirement, provided that the objective is legitimate and the requirement is proportionate". Although these terms are deliberately restrictive to avoid any abuse, the Commission does consider that "The term 'genuine 
the other areas covered by the Racial Equality Directive such as education, social protection, or social advantages, or in the access to and supply of goods and services which are covered also by Directive 2004/113/EC of 13 December 2004 implementing the principle of equal treatment between men and women, we may need to question the criteria we usually resort to for the allocation of these goods, in order to ensure that the disadvantages of members of minority groups are better tackled. More could be invested in education, for example, in the neighbourhoods where the immigrant population is concentrated; specific programmes could be developed to facilitate access to health services to nomadic populations, so that not only the health needs and the level of revenues are taken into account in the distribution of health services, but also the lack of access to such services which certain groups may experience; in general, we should proactively ask whether the usual criteria we use for the allocation of such goods are sufficiently sensitive to the needs of certain disadvantaged categories, even before asking whether forms of affirmative action should be developed in favour of these groups. At the same time, any attempt either to redefine these criteria in order to take into account these needs, or indeed any policy aimed at targeting specific categories defined by "suspect" characteristics for the distribution of certain benefits, should not become a disincentive for the adoption of more structural remedies which, once they will be put in place, will progressively bring about a situation where such special measures will be seen as redundant and unnecessary.

\section{Conclusion}

The recent Communication of the Commission "Non-discrimination and equal opportunities to all - A Framework Strategy", ${ }^{149}$ which results from the consultation process launched by the publication of the Green Paper on Equality and non-discrimination in an enlarged EU on 28 May 2004, ${ }^{150}$ states that:

"the implementation and enforcement of anti-discrimination legislation on an individual level is not enough to tackle the multifaceted and deep-rooted patterns of inequality experienced by some groups. There is a need to go beyond anti-discrimination policies designed to prevent unequal treatment of individuals. The EU should reinforce its efforts to promote equal opportunities for all, in order to tackle the

occupational qualification' should be construed narrowly to cover only those occupational requirements which are strictly necessary for the performance of the activities concerned. In the case of differences of treatment based on racial and ethnic origin, such cases will be highly exceptional. Examples of such differences might, for example, be found where a person of a particular racial or ethnic origin is required for reasons of authenticity in a dramatic performance or where the holder of a particular job provides persons of a particular ethnic group with personal services promoting their welfare and those services can most effectively be provided by a person of that ethnic group" (COM(1999) 566 final, of 25.11.1999, at p. 8).

$149 \operatorname{COM}(2005) 224$ final, 1.6.2005.

${ }^{150} \operatorname{COM}(2004) 379$ final, 28.5.2004. The reactions to the Green paper are available at:http://europa.eu.int/comm/employment_social/fundamental_rights/policy/anev al/green_en.htm. 
structural barriers faced by migrants, ethnic minorities, the disabled, older and younger workers and other vulnerable groups."

The time has come to rethink the anti-discrimination model on which the current Community legislative framework is based. A first step would be to consider whether disparate impact discrimination should not be outlawed in the Member States. This implies going beyond the current definition of indirect discrimination as included in the Racial Equality and Employment Equality Directives. Victims of discrimination should be allowed to establish a presumption of discrimination by bringing forward statistics, thus obliging the author of a measure creating a disparate impact on certain protected groups either to justify that measure as both appropriate and necessary to the fulfilment of a legitimate end, or to modify it (above, section 2). Contrary to what is sometimes assumed, the processing of data in order to monitor the situation of racial, ethnic or religious minorities, of persons with disabilities, of persons with different sexual orientations, or of age groups, is not prohibited under the existing legal framework relating to the protection of private life in the processing of personal data (section 3.1). A second step would consist in moving towards a model of affirmative equality, in which anti-discrimination law seeks to ensure not only a fairness of process, but also a fair distribution in the outcomes, by including obligations to adopt measures improving the situation of the most disadvantaged groups of society. Under this model of equality, affirmative action policies have a crucial role to play, as a tool to combat structural forms of discrimination which cannot be adequately responded to by the prohibition of individual instances of discrimination (section 4). Here again, this may be reconciled with the existing legislation protecting private life vis-à-vis the processing of personal data, provided certain safeguards are complied with (section 3.2).

In its Communication proposing its Framework Strategy on nondiscrimination, the Commission notes that "Positive measures may be necessary to compensate for long-standing inequalities suffered by groups of people who, historically, have not had access to equal opportunities". ${ }^{151}$ But this is not because, as suggested by the Communication, "it is difficult for legislation alone to tackle the complex and deep-rooted patterns of inequality experienced by some groups". There is a role for legislation in combating structural discrimination. ${ }^{152}$ Of course, social and economic policies are also required to fulfil this aim. But this should not exonerate us from improving the legislative framework to accommodate the needs of those who are underrepresented, and whose exclusion cannot be attributed solely to identifiable regulations, procedures or practices. Now is the time to act.

$51 \mathrm{COM}(2005) 224$ final, at para.3.3.

152 Christopher McCrudden, "Institutional Discrimination", 2(3) Oxford Journal of Legal Studies (1982), 303-367. 